IZA DP No. 8270

In 'Trusts' We Trust:

Socially Motivated Private Schools in Nepal

Sarmistha Pal

Bibhas Saha

June 2014 


\title{
In 'Trusts' We Trust: Socially Motivated Private Schools in Nepal
}

\author{
Sarmistha Pal \\ University of Surrey \\ and IZA
}

Bibhas Saha

University of East Anglia

\author{
Discussion Paper No. 8270 \\ June 2014
}

IZA
P.O. Box 7240
53072 Bonn
Germany

Phone: +49-228-3894-0

Fax: +49-228-3894-180

E-mail: iza@iza.org

\begin{abstract}
Any opinions expressed here are those of the author(s) and not those of IZA. Research published in this series may include views on policy, but the institute itself takes no institutional policy positions. The IZA research network is committed to the IZA Guiding Principles of Research Integrity.

The Institute for the Study of Labor (IZA) in Bonn is a local and virtual international research center and a place of communication between science, politics and business. IZA is an independent nonprofit organization supported by Deutsche Post Foundation. The center is associated with the University of Bonn and offers a stimulating research environment through its international network, workshops and conferences, data service, project support, research visits and doctoral program. IZA engages in (i) original and internationally competitive research in all fields of labor economics, (ii) development of policy concepts, and (iii) dissemination of research results and concepts to the interested public.
\end{abstract}

IZA Discussion Papers often represent preliminary work and are circulated to encourage discussion. Citation of such a paper should account for its provisional character. A revised version may be available directly from the author. 


\section{ABSTRACT \\ In 'Trusts' We Trust: Socially Motivated Private Schools in Nepal ${ }^{*}$}

We study school choice and school efficiency in terms of secondary school completion test scores by utilizing a unique database from Nepal. There are two novel features of our analysis: firstly we allow for heterogeneity among private schools, by distinguishing socially motivated trust-run schools from profit-motivated company-run schools, and secondly, we include school's expenditure as a determinant of its efficiency per unit of cost. We find that when expenditure is not included, the trust-run school comes on top, slightly but distinctly, ahead of the profit-motivated school. But if expenditure is included, the trust-run school's position becomes sensitive to the level of expenditure, as it is the only school to exhibit sensitivity between expenditure and test score. In the urban area, the public school is always at the bottom, and between the two types of the private school the trust-run school ranks first (second) at high (low) levels of expenditure. However, in the rural area it is a three way race, with the trust school coming on top again at high expenditure, but falling to bottom at low levels of expenditure. This picture is fairly robust to considerations of subject fixed effects and to inclusion or exclusion of private aided schools or private tuition. We show both theoretically and empirically that socially motivated schools can be efficient and outperform profitmotivated schools.

JEL Classification: H44, I22

Keywords: private school heterogeneity, school expenditure per student, efficiency, private school premium, social objectives, private motive,

rural-urban dichotomy, Nepal

Corresponding author:

Sarmistha Pal

Management School Building

Faculty of Business, Economics and Law

University of Surrey

Stag Hill, Guildford, GU2 7XH, Surrey

United Kingdom

E-mail: s.pal@surrey.ac.uk

\footnotetext{
* Sarmistha Pal gratefully acknowledges the funding from Leverhulme Trust, data and related information from Saurav Bhatta and Uttam Sharma and also the hospitality of the Department of the Applied Economics at the University of Minnesota, where this research was initiated. We are much grateful to Paul Glewwe for the initial idea of the paper and to Andrew Griffen, Javeria Qureshi, Sandra McNally, Harry Patrinos, Nisith Prakash, Uttam Sharma and Prakarsh Singh for the very constructive comments on an earlier draft of the paper. We would also like to thank participants at the Econometric Society Asian Meeting in Singapore and Mid-West International Economic Development Conference at Minneapolis. The usual disclaimer applies.
} 


\section{Introduction}

The exisiting literature on the relative efficiency of private schools over public schools commonly treats the private education sector as a monolithic and homogenous entity. This seems to be at odds with reality, where in developing countries the private schools seem to come with great variety. In a global report EdInvest (2000, pp. 5-7) identified six tiers of private schools in developing countries ranging from very inexpensive schools for the poor to very costly schools for the rich. ${ }^{1}$ Such heterogeneity may actually reflect different objectives pursued by different types of schools, and some of them may be more socially motivated than being profit maximizer. When such diversity is explicitly modelled, one may detect differential efficiency in the private (or non-state) sector. Socially motivated schools can outperform the profit-motivated schools, which have been traditionally found to be more efficient than state-run schools (Jimenez et al 1988; 1991; 1995; Kingdon 1996; Sharma, 2011; Desai et al., 2009; Muralidharan and Sundararaman, 2013)2 .

In this paper, we test this possibility using a unique dataset from Nepal. We also try to ascertain the channels through which a socially motivated schools may attain greater efficiency. There is only a few studies that have found public schools to be superior to private schools, namely Beegle and Newhouse (2006) for Indonesia, Somers et al. (2004) for Latin America, and Chudgar and Quin (2012) for India. ${ }^{3}$ Conceptually, profit motive need not be in conflict with educational objectives. Strong test performance justifies asking for high admission/tuition fees, resulting in greater profits. But in developing countries, high fees can be due to local monopoly, abysmal quality of local public schools, and above all the high cost of physical infrastructure. Therefore, profit motive may encourage to take in many more students, or cut corners on some essential learning inputs; it is also possible to spend on many extra curricular activities, that are not complementary to exam-oriented learning. Socially motivated schools, on the other hand, are likely to be geared to achieving higher test performance, within their finacial constraints enforced by low tuition fees or donor's conditions. ${ }^{4}$

Since 1992 all non-governmental schools in Nepal are legally required to be registered either as a private limited company or as a (non-profit) trust, none receiving government funds. With this liberal policy, the so-called company-run school sector has attracted significant private investments. By their own choice and declaration, these schools are profit-maximizers. The trust schools, on the other hand, are a minority, and expected to be non-profit. Though one can suspect the trust schools to be profit-maximizer in disguise, there are ample evidence to believe that such suspicion is untrue. First, these schools are a minority; they constitute only $3 \%$ in our sample, compared to $18 \%$ schools being run by companies. Were it profit-

\footnotetext{
${ }^{1}$ See also Tooley and Dixon (2003) for private schools catering to the poor in India.

${ }^{2} \mathrm{An}$ important exception is Beegle and Newhouse (2006) for Indonesia - see further discussion below.

${ }^{3}$ Beegle and Newhouse (2006) showed that in Indonesia at the junior second level (grades 7-9), public schools outperform the private schools; the authors attribute the success of the public schools to unobserved higher quality of inputs used in public schools. Similarly, using comparable surveys across 10 Latin American countries, Somers et al. (2004) failed to find a strong and consistent private school effect once household, student and the peer group characteristics are taken into account. Chudgar and Quin (2012) show that low-fee paying private schools are no better than the public schools. They emphasize the need for recognzing heterogeneity among profit-motivated schools.

${ }^{4}$ The importance of social objectives in providing public good is well recognized (Besley and Ghatak, 2007). It is also known that engagement with religious and social organizations can compensate for disadvantages (such as broken family, extreme poverty and loss of parents) suffered earlier in life (Dahejia et al., 2007).
} 
seeking, we would have seen substantial entry into this sector. Second, these schools existed long before the company-run schools came into existence. There is a long history of trust schools in Nepal, being funded by philanthropers and religious groups who were known to be promoter of education (and plausibly other social objectives). ${ }^{5}$ Third, two types of the private schools often disagreed in public over the education policy of the government; see Caddell (2007), and Carney and Bista (2009). Fourth, in our econometric estimation, we can verify whether their behaviours are similar or different.

At a theoretical level also, we can examine whether and how different objectives can lead to different configurations of school enrolment and choice of different levels of expenditure. Using the basic structure of Epple and Romano (1998), but significantly simplifying it, we study school fee choice and expenditure decisions of a profit-maximizing school and a socially motivated school, holding a public school as a default choice. We show that the socially motivated (trust) school is most efficient user of resources toward maximizing the expected test score of its students. The profit-oriented (company-run) school, on the other hand, will choose an expenditure level that will equate the marginal cost with the marginal admission revenue, regardless of whether the expected test score is maximized or not. This means, for trust-run schools efficiency is achieved mainly by the expenditure route, while that may not be the case in company-run schools.

We use a nationwide survey data of students, schools, teachers, and families in 2002, 2003 and $2004 .{ }^{6}$ The dataset contains students' individual characteristics and test scores, and detailed information on their schools, which not only allow us to detect rural-urban difference between the two types of private schools, but also to exploit the exogenous variation in school expenditure per student (see discussion below) to identify a causal mechanism explaining the effect of private school types (vis-a-vis public schools) on student performance. The measure of efficiency we use is the standarised test scores at the school leaving certificate examination (SLC for short).

Our empirical model proceeds in two stages, dealing with school choice first and estimation of school efficiency next, focussing on expenditure per student as the channel of efficiency. ${ }^{7}$ We are conscious that two important factors, namely parental demand on the school to perform better and the school's own aspiration or efforts (if any) to do so, can also be the drivers of school expenditure. But as these factors are unobservable, we need to minimize the bias arising from their omission. Unfortunately, our data do not permit a household fixed effect model to address the parental demand issue; but we control for a range of individual and household as well as community characteristics to get a grip over it. We also consider a subject-level pseudo-panel for each individual to eliminate household/individual level unobserved heterogeneity.

School's unobserved effort or aspiration can potentially create a simultaneity problem between its ex-

\footnotetext{
${ }^{5}$ For example, Pahar Trust Nepal is a well-known trust that aims to promote education in poorest areas. Apart from building schools in the remote areas of East and West Nepal, it tries to build clean water provision systems, hostels, health posts, nurseries as well as operate teacher training and child sponsorship schemes in several different districts of Nepal. Similarly, Nepal Schools Trust is a Scottish charity working to educate children among farming communities.

${ }^{6}$ Although there are more recent rounds of Nepal Living Standard Survey data, such as that of 2010, this data do not have the detail school and teacher level information that we need for our analysis.

${ }^{7}$ Given our focus on private schools, we do not consider the issue of allocation of funds to public schools by local governments, as it might be important in other contexts (see Steele et al, 2007).
} 
penditure and test scores. To resolve this problem we use the three years average expenditure (from 2002 to 2004) rather than the contemporaneous expenditure. In addition, the school dummy will capture any unobserved effect relating to the school type (e.g., head teacher's autonomy, teacher's quality etc) that may influence the student test scores. Any unobserved time-varying effect is captured by year dummies and their interaction with school types in our pooled sample of 2002-04.

For the first stage regression, we use the presence of a fully funded government school in the community as determined by the administrative authority (and as such beyond the influence of private individuals) as an an identifying variable. We see that richer households are more likely to choose a company-run school and backward community households (namely Dalit) are also more likely to choose a trust-run school. This pattern tallies with our theoretical model pertaining to household choice.

For the second stage regression, we first note that certain individual and household characteristics matter. For instance, male students perform better, and with higher age some increasing returns also set in. Parents' graduate education helps, but not their incomes. We have also added a dummy to see whether the student has repeated grade nine or not. This is meant to capture student's 'ability' to some extent. Student who, did not repeat grade nine, are expected to be acamdemically better students than those who did. Indeed, these students seem to have higher test scores to the order of $9.11 \%$ standard deviation. ${ }^{8}$

Next, we turn our attention to school characteristics. When the school premium is identified only by including a school dummy, the trust school comes on top, slightly but distinctly, ahead of the company-run school, both types appearing to be substantially superior to the government schools. But when we include the school's expenditure per student and interact it with the school type dummy, we see that expenditure matters only for the trust-run schools. Higher expenditure improves the test score in trust schools, but it comes with a fall in the trust school's intercept. Consequently, the hierarchy of the three types of school becomes sensitive to the expenditure level they choose. At high levels of expenditure, the trust schools are the winner, and at low levels of expenditure the company-run schools are the winner. However, in the rural sector, it becomes a three way race, with government schools coming second at low levels of expenditure.

We check if this relationship holds, if instead of total expenditure only the teachers' salaries (again we consider 3 year average salaries) are considered, because teaching is the key input in this environment, and salaries of teachers constitute the bulk of expenditures in all schools. We are pleased to see that the same pattern remains valid. One may, however, argue that expenditure figures are not necessarily accurate. To address this concern, we also replace expenditure per student by pupil-teacher ratio, which may be seen as an outcome of expenditure. Again, our central result is confirmed; in this case the trust school comes out much more superior to both the public school and the company run school unconditionally. The superiority of the trust school is fairly robust to few other considerations as well, such as the subject fixed effets and inclusion or exclusion of private aided schools and private tuition. Superiority of trust schools is confirmed even when we distinguish between low and high fee company schools. We also show that inclusion of schools that are

\footnotetext{
${ }^{8}$ Some indirect measure of ability has been captured through subject fixed effect regressions.
} 
somewhat semi-public, which receive substantial fund from the government but are managed autonomously by parents' representatives, also does not change our key results.

That trust schools are behaving differently, as a school and also as a user of resources, to the companyrun school is a testimony to the fact that they are pursuing a different objective other than profit, because all company-run schools cannot be anything other than profit-seeking by their own admission. So if the company-run schools are behaving differently, it is because they are purusing some social objectives.

Our findings are also consistent with the literature that finds positive private school premium, but treats all private schools as a monolithic entity. We have shown that ignoring heterogeneity can lead to wrong conclusions. In this context, we should mention the work of Sharma (2011) who has used the same data as ours, but did not allow heterogeneity, and found the prevalence of a private school premium. But as we have shown that gives only an incomplete picture. ${ }^{9}$

The paper is organized as follows. Section 2 discusses the context of our study and the data. Section 3 provides a small theoretical model, and Section 4 presents the econometric model. In Section 5 we discuss the results and various robustness checks. Section 6 concludes.

\section{Background and Data Description}

It is important to note that Nepal has undergone two remarkable experiences in recent times. First, it made transition from monarchy to multi-party democracy in 1990, following which the country witnessed a dramatic growth of private schools. ${ }^{10}$. But the transition to democracy was marred by violent conflicts between the Maoist Communist Party and the government from 1996 to 2006. The conflict ended with the Communist Party joining mainstream politics. One of the Maoist demands was to impose a tuition fee cap in private schools, which the government accepted in May 2002. This is known as the Private and Boarding School Organisation (PABSON) Code of Conduct. In general, in the post-conflict Nepal education received greater attention, in recognition of the need to prevent future rebellion (ILO, 2008).

\subsection{History of private schools in Nepal}

The history of modern schooling in Nepal began in 1853 when the then King (though called Prime Minister) set up a school for his Royal family. ${ }^{11}$ It is only after 1950, government started schools for the general public;

\footnotetext{
${ }^{9}$ Sharma (2011) obtained a significantly positive private school effect in English, Math, Science and Health/Physical Education (though not in Nepali and Social Studies).

${ }^{10}$ More importantly, the English-medium instruction offered in most private schools emerged as an important source of differentiation, as Liechty (2003) notes: 'English proficiency is simultaneously the key to a better future, an index of social capital, and part of the purchase price for a ticket out of Nepal'. Nevertheless, Nepal's multilingual, multiethnic and multicultural character presents a great challenge to achieving the target of education for all with a view to ensure decent job opportunities and better lives for young people.

${ }^{11}$ Janga Bahadur Rana, a Rana Prime Minister, recognized the need of education after his visit to England and established Nepal's first school, Durbar High School, which was an English medium school meant only for the royal family (Government of Nepal: Ministry of Education, 2009; Khaniya, 2007).
} 
however, initiatives started also at the community levels to build schools without government support. Such schools were called non-government schools (Khaniya, 2007).

However, the Education Act 2028 (passed in 1971) nationalized all the existing non-governmental schools, thus hindering the growth of private sector education (Khaniya, 2007). But it was soon realized that the government could not provide education for all and hence the Education Act 2028 was amended in 1980 to create room for private sector involvement. Since mid-1980s the number of private schools began to grow (Save the Children, UK, South and Central Asia, 2002). Finally, with Nepal's transition to democracy in 1990 the private sector got a big boost. Private schools mushroomed, especially in the urban areas (Khaniya, 2007).

The Seventh Amendment of the Education Act 2028 (passed in 1992) decreed that the private schools be registered as either a private limited company or a trust (Gautam, 2008; Khaniya, 2007). Hence the private schools in our dataset are called either company-run schools or trust schools. There is yet another type of school, which are a close cousin of the government-run school, called partly-aided private schools. These schools are almost nearly fully funded by the government, but its management wrests with an elected body.

\section{$2.2 \quad$ Data}

Our dataset is taken from a national survey commissioned by the Ministry of Education of Nepal to assess student- and school-level determinants of success on the SLC from 2002 to 2004 (see Bhatta 2005 for further details about the survey). ${ }^{12}$ We primarily focus on the government, company-run and trust-run schools, and drop the partially aided private schools (for being a hybrid), though later on we include them for a robustness check of our central results. Between the two types of private schools, the company run schools are expensive and registered as profit-seeking firms, while the trust schools are likely to be socially motivated (see Table 1 for a comparison between these two types of schools).

Our sample covers students repeating SLC examinations over 2002-2004; but we primarily focus on those who are attempting for the first time in $2004 .{ }^{13}$ This is because we want to eliminate any estimation bias arising from the inclusion of the repeaters as well as to avoid recall problems. ${ }^{14}$

From the detailed school level income and expenditure data we create a school level variable of total expenditure per student for each of the survey years 2002-04 and adjust them by the 2000 price level to generate the three year average school expenditure per student. ${ }^{15}$ We prefer this 3-year average to contemporaneous expenditure as it is a more long-term measure of expenditure and hence a better determinant of student performance. Also, it will minimise the problem of potential simultaneity between school expenditure per

\footnotetext{
${ }^{12}$ The SLC exam consists of tests in six compulsory subjects (Nepali, English, Mathematics, Science, Social Studies, and Health/Physical Education) and two optional subjects.

${ }^{13}$ About $64 \%$ of the sample students appeared for SLC as a first attempt; little over one third of students failed earlier and had to repeat SLC subsequently, most of them being from government schools. About $74 \%$ of students attending private schools (as against only $5 \%$ in government schools) had English as a medium of instruction.

${ }^{14}$ Further, the political climate in the year of 2004 was more stable.

${ }^{15}$ Total expenditure of a school is composed of expenditure on staff salaries, training, educational materials, sports equipment and activities, office supplies and stationary, repair and maintenance, capital and infrastructure development.
} 
student and student performance, if any.

In addition, we include the private school type dummies, which proxy for differences in unobserved characteristics such as the head teacher's administrative autonomy, teacher's unionisation rate, incidence of regular homework or weekly test etc. We will be interested to see how these dummy variables and expenditure per student affect the test scores, individually and/or interactively.

We observe both total and subject level test scores obtained by each student in the SLC final exams. We standardise each test score (total as well as subject-level) by subtracting it from its sample mean and then dividing by its standard deviation. Table 1 compares some selected characteristics of government and two types of the private schools in our sample of 2004 . Out of all 5778 sample schools in 2004, about $80 \%$ were fully government funded (64\%) and private aided (16\%) schools; among the rest, $3 \%$ were trust run while little above $16 \%$ were company run private schools. First, the profit motive of company (relative to trust and governent) schools is highlighted in school fees (tuition, exam, library and others) as a share of total income: it is $119 \%$ in company schools as opposed to $71 \%$ in trust schools and only $2 \%$ in government schools. Second, company-run schools rank above the other two types of schools in terms of ordinary and standardised test scores. We also see that the total number of teachers is higher and the number of pupils per teacher is much lower in company run schools. In contrast, presence of unionised teachers and proportion of teachers never teaching for the entire period are generally higher in government schools closely followed by trust schools. Finally, the share of total expenditure spent on teachers' salaries is comparable in the two types of private schools in our sample, which is much lower than that in the government schools. Thus, these three types of schools not only differ in terms of expenditure per student, but also in terms of choice of teaching and non-teaching inputs, which in turn may explain their differential performance.

Table 2 performs the mean comparisons of selected characteristics of company-run schools and government schools. As expected, the company-run schools are well resourced, and so they have a much higher expenditure per student. It is also the case that in many of these schools head teachers have full autonomy in disciplining the teachers, who in turn seem to put in greater efforts (as reflected in lower teachers' unionization rate, higher proportion of these teachers teaching the entire period and also use both lecture and interactions with students). Consequently, the average standardised SLC test scores of students from company- run schools are significantly higher than those from state schools.

In Table 3, we compare company-run schools between rural and urban areas (see Table 3). On an average, students in urban areas have higher scores. The diffrence in the expenditure pattern is also striking. The head teachers also enjoy less autonomy in rural schools. A similar rural-urban divide exists among the trust schools as well (see Table 3A) in terms of test scores, but not with the expenditure per student.

Finally, we examine the non-parametric relationship between log expenditure per student and standardised test scores by the graph of Epanechnikov kernel-weighted local polynomial regression in Figure 1. Panel $a$ concerns all schools and panels $b-e$ concern different groupings of schools. All these graphs exhibit a common increasing trend of test scores (rather non-linearly) against log expenditure. Initially the test score 
does not increase much, but after a point there is a sharp increase, and then the scores oscilate (with the exception of the trust school, see panel $e$ ). The critical value of log expenditure at which the score seems to take off occurs much earlier at the companry-run schools than the trust-run schools. In state schools, the take-off is less pronounced; but at high levels of expenditure there is a vertical drop, which is probably more of an artefact of fewer datapoints.

Figure 2 shows the sensitivity of salary and non-salary components of expenditure to changes in $\log$ expenditure increases for trust and company schools. The figure highlights the differential behaviour of trust and company run schools in this respect: evidently, trust schools increase the share of expenditure on non-teaching inputs as total expenditure increases; the pattern is quite different for company schools who tend to increase (decrease) expenditure on teaching (non-teaching) inputs when log expenditure increases beyond 2 .

While these graphs highlight the differential pattern of expenditure allocation and also differential expenditure sensitivity of standardised total test scoress for different school types in our sample, it is imperative for us to examine if these relations hold, after taking account of all other factors that may influence test scores. This will be discussed in sections 4 and 5 .

\section{A Theoretical Model}

Now we propose a simple theoretical model of school choice to motivate our empirical model. This will also be helpful in understanding how test score differentials may emerge out of school competition. Suppose there are $N$ families with one student each, and there are three schools indexed by $i$, - a public school (indexed $i=0$ ) charging no fees, a trust-run school which is run by a non-profit organization $(i=1)$ and a profit-maximizing company-run private school $(i=2)$. The households differ only in terms of income, which is given by an income distribution function $\Psi(y)$ with density $\psi(y)>0$ at all $y \in[0, \bar{y}]$.

Students do not differ in ability in our model, though this can be an important driver of school choice (Epple and Romano, 1998). ${ }^{16}$ Each school is characterised by an exogenously (or historically) given capital good $\left(K_{i}\right)$ representing its infrastructure that cannot be changed overnight; in addition, they make an annual expenditure $\left(H_{i}\right)$ on teaching and associated inputs (including teachers' salary). We refer to $H_{i}$ as a schoolspecific public good, that is crucial for students' learning and their test scores. After completing schooling students receive their individual test scores by a random draw of nature. What matters for our analysis is the school-specific expected score that all parents face ex ante, which we denote as $\alpha_{i}$, (assume $\left.\alpha_{i} \leq 1\right)$. The expected score positively depends on total expenditure (increasing returns) and negatively depends on the number of students $n_{i}$ (congestion effect) ${ }^{17}: \alpha_{i}\left(H_{i}, n_{i} ; K_{i}\right), \partial \alpha_{i} / \partial H_{i}>0, \partial \alpha_{i} / \partial n_{i}<0$. We also assume

\footnotetext{
${ }^{16}$ Epple and Romano (1998) provide a monopolistic competition model of private school competition. They do explicitly model peer affect by sorting students in terms of ability; however they do not have congestion. Nor are households credit constrained in their model.

${ }^{17}$ We can easily accommodate both positive group-size effects as well as negative congestion effects. In that case $\partial \alpha_{i} / \partial n_{i} 0$ will be initially positive, and then turn negative after a critical value of $n_{i}$.
} 
for simplification $\partial^{2} \alpha_{i} / \partial H_{i}<0, \partial^{2} \alpha_{i} / \partial H_{i} \partial n_{i}=0, \partial^{2} \alpha_{i} / \partial n_{i}<0$. Note that the test score function can be different across schools, because of their initial choice of $K$. We assume that a larger $K$ will shift the test score function upwardly.

The public school: The public school offers a default choice free of cost. It spends an amount $H_{0}$, which is given by the government. Depending on the number of students that choose to come here, its expected score will be given by $\alpha_{0}=\alpha_{0}\left(H_{0}, n_{0}\right)$ (suppressing $K_{0}$ ) where $n_{0}$ is the number of students. There is no restrictions on the number of students that can be admitted.

The trust-run school: There is an educational trust that wants to educate the poor children and also impart some 'social' skill/behaviour. It imparts learning just like any other school by spending $H_{1}$ on a public good, but it also spends $x$ per student to teach them some social behaviour (such as discipline or moral behaviour in a faith school). On the revenue side, the trust receives $D$ from a charity or donor, and it raises some additional revenues by charging a fee $F_{1}$ per student. It is reasonable to assume that the donor may restrict the trust from charging any arbitrary fee; so it fixes $F_{1}$ along with $x$, but leaves it to the trust to decide how many students it may admit, provided it spends all of its revenues. Further, to enforce its social obligation the trust is required to admit the poorest $n_{1}$ students from those who can afford the fee $F_{1}$. The aim of the school is to maximize a combination of an educational objective and a social objective, subject to spending all of its revenue. More formally, it chooses $n_{1}$ to maximize

$$
\begin{array}{ll} 
& Z=\alpha_{1}\left(H_{1}, n_{1}\right)+w(x) \\
\text { s.t. } & H_{1}+n_{1} x=D+n_{1} F_{1} .
\end{array}
$$

The company-run school: The profit-motivated company-run school admits $n_{2}$ students for a tuition fee of $F_{2}$ per student and it also incurs an expenditure $H_{2}$. There is, however, a tuition fee cap $\bar{F}_{2}$, as implied by the PABSON Act of Nepal which came into force during our study period. Students expect here to get an expected score $\alpha_{2}$. Formally, the company-run school maximizes $\pi_{2}=n_{2} F_{2}-H_{2}$, by announcing $\left(n_{2}, F_{2}, H_{2}\right)$ subject to $F_{2} \leq \bar{F}_{2}$.

These assumptions can be justified in the light of available inforation as we observe different sources of income of each school in our sample. Total income includes income from Grants in aid, government development grants, grants from local development, grants from NGOs, INGOs and other development partners. It also includes income from private donations, interest on school's capital, fundraising, rental income, sales of school's produce and school fees on admission, readmission, tuition, library, examination etc, which are more important for private unaided schools. Table 1 summarises average expenditure per student, salary per teacher, school fees per student and also school fees as share of total income for fully funded government and unaided trust and company schools in our sample. We find that (i) school fees per student is significantly higher in company run schools; (ii) further school fees as share of income is $119 \%$ (71\%) in company (trust) schools, which we take as an evidence that company-run schools are profit 
motivated while trust schools are socially motivated.

The household's choice: Parents are expected utility maximizers. They live for two periods with same income in each periods. In the first period, they decide which school to choose. If a non-state school is chosen, after paying the fee, they consume the rest of the income. In the second period, students receive their test score which contributes to the parents' utility. A representative parent with income $y$ has the expected utility from choosing school $i$ as $E u_{i}(y)=\left(y-F_{i}\right)+\delta y \alpha_{i}$, where $\delta$ is the discount factor. From the default choice the parent's expected utility is $E u_{0}(y)=y\left(1+\delta \alpha_{0}\right)$.

Timeline: As mentioned earlier, there are two periods; but in the second period no decisions were taken. In the first period, we assume, decisions are taken in three stages.

Stage 1: The trust school announces $n_{1}$ seats, subject to the restriction that they will have to be the poorest students with ability to pay $F_{1} ; D$ and $x$ are known to the households. The government school is already there with $H_{0}$ as its expenditure.

Stage 2: The company-run school announces $n_{2}, F_{2}$ and $H_{2}$.

Stage 3: Parents decide which school to send their children to. Market clears: $N=n_{0}+n_{1}+n_{2}$.

Stage 3. Let us begin from stage 3. Parents observe how many students the trust school and the company-run school would like to admit and at what tuition fees. They also see their expenditures. Assuming that the target admission numbers will be realised, parents can figure out $\alpha_{2}, \alpha_{1}$ and $\alpha_{0}$ from the function $\alpha\left(H_{i}, n_{i}\right)$, and then calculate their utility of choosing a specific school.

Those who did not qualify for the trust school (for not being poor enough) will have to choose between the company-run school and the public school. Those who did qualify for the trust school and can afford the company-run school fee will have three choices, and finally those with income less than $F_{1}$ have no choice other than the public school. So depending on how high the company-run school's fee is, there are several scenarios to cosider. For simplification, suppose the turst school's policy is not to admit any child whose parent earns more than $y^{T}\left(<\bar{F}_{2}\right)$, and the private school sets $F_{2}\left(\leq \bar{F}_{2}\right)$ above $y^{T}$ to target the richer section of the population. Thus, all parents whose incomes exceed $F_{1}$ have only two choices - either trust school as opposed to the public school, or the company-run school as opposed to the public school.

Parents whose incomes fall between $F_{1}$ and $y^{T}$ will choose the trust school if $E u_{1}(y) \geq E u_{0}(y)$. If the school is over-subscribed (i.e. the number of willing and eligible students exceeds $n_{1}$ ), priority is given to a poorer $n_{1}$ families. The household which is indifferent between choosing the public school and the trust school must have income $\hat{y}_{1}=\frac{F_{1}}{\delta\left(\alpha_{1}-\alpha_{0}\right)}>F_{1}$.

In Figure 3, we have shown how $\hat{y}_{1}$ would exceed $F_{1}$. All households with income greater than $\hat{y}_{1}$, but less than $y^{T}$, would prefer to be in the trust school, but only $n_{1}$ are admitted, as shown in Figure 3. Similarly, a household with income greater than $F_{2}$ will be indifferent between the company-run school and the public school, if its income is $\hat{y}_{2}=\frac{F_{2}}{\delta\left(\alpha_{2}-\alpha_{0}\right)} \cdot{ }^{18}$ All families with income $\hat{y}_{2}$ choose the company-run school. Finally,

\footnotetext{
${ }^{18}$ For $\hat{y}_{2}>\hat{y}_{1}$ we implicitly assume $\frac{F_{2}}{F_{1}}>\frac{\alpha_{2}-\alpha_{0}}{\alpha_{1}-\alpha_{0}}$.
} 
as shown in Figure 3 the public school, which absorbs all the remaining children, will have a mxied batch the poorest children and a group of middle class children, who are not poor enough to get into a trust school and also not rich enough to go to the company-run school.

Of course, it is possible that the private school may be oversubscribed, or undersubscribed. But the school can avoid these two 'disequilibrium' situations by revising the expenditure. So we restrict our attention to the equilibrium case, where the parent indifferent between the public school and the private school is the $n_{2}$-th parent. Thus, the market clearing condition for our model is

$$
n_{2}=N\left[1-\Psi\left(\hat{y}_{2}\right)\right]
$$

where

$$
\hat{y}_{2}=\frac{F_{2}}{\delta\left(\alpha_{2}-\alpha_{0}\right)}=\frac{F_{2}}{\delta\left(\alpha_{2}\left(H_{2}, n_{2}\right)-\alpha_{0}\left(H_{0}, N-n_{1}-n_{2}\right)\right)} .
$$

The right hand side of Equation (1) represents the number of students seeking admission, and the left hand side is the number of students the company-run school has announced to admit. With the announcement of a larger $n_{2}$ (holding other things unchanged), the critical value of $y_{2}$ will rise, as $\alpha_{2}$ will fall and $\alpha_{0}$ will rise. Consequently, the number of students seeking admission into the company-run school will fall. Thus, the $\left[1-\Psi\left(\hat{y}_{2}\right)\right]$ curve is downward sloping in $n_{2}$, and it is bound to cross the 45-degree line, where we achieve the equilibrium.

Stage 2. Now moving on to stage 2, we solve the company-run school's problem. Anticipating the school demand in stage 3 the company-run school maximizes $\pi=n_{2} F_{2}-H_{2}$, subject to $F_{2} \leq \bar{F}_{2}$ and the market clearing condition (1). We can set the Lagrangian of the problem as

$$
L=n_{2} F_{2}-H_{2}+\lambda\left[N\left\{1-\Psi\left(\hat{y}_{2}\right)\right\}-n_{2}\right]+\mu\left[\bar{F}_{2}-F_{2}\right]
$$

The unconstrained case: We first consider the case where $F_{2}<\bar{F}_{2}$, so that $\mu=0$. The first order conditions are:

$$
\begin{aligned}
\frac{\partial L}{\partial n_{2}} & =F_{2}-\lambda N\left[\psi\left(\hat{y}_{2}\right) \frac{\partial \hat{y}_{2}}{\partial n_{2}}+1\right]=0 \\
\frac{\partial L}{\partial F_{2}} & =n_{2}-\lambda N \psi\left(\hat{y}_{2}\right) \frac{\partial \hat{y}_{2}}{\partial F_{2}}=0 \\
\frac{\partial L}{\partial H_{2}} & =-1-\lambda N \psi\left(\hat{y}_{2}\right) \frac{\partial \hat{y}_{2}}{\partial H_{2}}=0 \\
\frac{\partial L}{\partial \lambda} & =\left[1-\Psi\left(\hat{y}_{2}\right)\right]-n_{2}=0 .
\end{aligned}
$$

Equations (3) and (4) speicfy how $n_{2}$ and $F_{2}$ are to be used so that the total revenue is maximum. With an increase in $n_{2}$ the company-run school's revenue goes up by $F_{2}$, but at the same time its market contracts because of a decrease in the test score differential $\left(\alpha_{2}-\alpha_{0}\right)$. A similar tradeoff is felt when $F_{2}$ is raised. 
Equation (5) shows that there is a marginal gain in the market share from an increase in $H_{2}$ which at the optimum must be equal to 1 dollar spent at the margin. The last equation ensures that the number of school places demanded match with the number of places offered.

A graphical illustration of the company-run school's choice might be instructive. Suppose we substitute the optimal $n_{2}$, denoted as $n_{2}^{*}$ in Equations (4) and (5) and then dividing (4) by (5) we obtain the following equation:

$$
\left(\frac{\partial \pi / \partial F_{2}}{\partial \pi / \partial H_{2}}\right)=\left(\frac{\partial \hat{y}_{2} / \partial F_{2}}{\partial \hat{y}_{2} / \partial H_{2}}\right)
$$

The ratio of the marginal effects of tuition fee and expenditure on school profit must be equal to the ratio of the marginal effects on the critical (i.e. indifferent) household. This is shown in Figure 4 . On the $\left(F_{2}, H_{2}\right)$ plane the school faces a family of iso-profit curves, which may be shaped like inverted U. ${ }^{19}$ The school is trying to reach the highest iso-profit curve by moving south-east as lower expenditure means higher profit (despite some adverse effect on $n_{2}$ ). But there is a constraint - the so-called market demand. The isoenrolment curves show the combinations of $F_{2}$ and $H_{2}$ that hold the number of students unchanged at some level. ${ }^{20}$ An increase in $F_{2}$ must be matched by an increase in $H_{2}$ to maintain the same $n_{2}$. The unconstrained optimum is given at point $E$ where an iso-profit curve is tangent to the iso-enrolment curve $n_{2}^{*}$.

The constrained case: When $F_{2}$ is restricted to be $\bar{F}_{2}$ (below the schools' optimum, there will be oversubscription, which can be eliminated by reducing $H_{2}$ from the unconstrained optimum. As shown in Figure 4, the constrained choice now occurs on the vertical line $\bar{F}_{2}$ where the iso-enrolment curve $n_{2}^{\prime}$ and iso-profit curve $\pi_{2}^{\prime}$ intersect each other. Clearly, the school's profit is less than the unconstrained case, and it enrols more students, but also incurs a smaller expenditure.

Formally, Equation (4) becomes irrelevant. Equations (3), (5) and (6) will determine the optimum $\left(H_{2}, n_{2}\right)$. However, as $n_{2}$ is given by the market clearing condition, and $F_{2}$ is set exogenously, it is $H_{2}$ alone that the company-run school can freely manipulate. In this sense Equation (5) is crucial. The sign of $\frac{\partial \hat{y}_{2}}{\partial H_{2}}$ is negative signifying an increase in the compnay-run school's market size. By combining Equations (3) and (5) we derive

$$
1=\bar{F}_{2}\left[\frac{\left(\partial \hat{y}_{2} / \partial H_{2}\right) \psi\left(\hat{y}_{2}\right)}{1+\left(\partial \hat{y}_{2} / \partial n_{2}\right) \psi\left(\hat{y}_{2}\right)}\right] .
$$

The left hand side represents the additional cost of raising expenditure, which is just 1 . The right hand side gives the additional benefit of increasing expenditure, which comes from expanding the market share. The bracketed term is the expected increase in additional enrolment, which is then multiplied with the exogenously set tuition fee $\bar{F}_{2}$ to give the marginal benefit of expenditure. It is then straight forward that the company-run school's choice of enrolment and expenditure should be such that its marginal impact on

\footnotetext{
${ }^{19}$ The inverted $\mathrm{U}$ shape can be hypothesized in the following way. Starting from a given $\left(F_{2}, H_{2}\right)$, if $F_{2}$ is increased, it must be accompanied by an increase in $H_{2}$ to hold profit unchanged. But higher $F_{2}$ will reduce $n_{2}$ while $H_{2}$ may reverse that. So the effect on $n_{2}$ is ambiguous. However, we can assume that after a point with further increases in $F_{2}$ the negative effect on $n_{2}$ is so strong (high elasticity) that it pulls down revenue and therefore to maintain the same profit expenditure will have to be lowered. This explains the inverted $\mathrm{U}$ shape of the iso-profit curve.

${ }^{20}$ Though mathematically the constraint is stated in terms of $\hat{y}_{2}\left(n_{2}^{*}\right)$, it is probably more instructive to restate it in terms of $n_{2}^{*}$, because one implies the other.
} 
the market share is just $1 / \bar{F}_{2}$.

Proposition 1. If the tuition fee caps binds, more students are likely to be admitted in the company-run school relative to the unconstrained case, which indirectly helps to reduce congestion in the public school and thereby the average test score of the public school will rise. But on the flip side, the expenditure of the company-run school will fall and so will its average test score $\alpha_{2}$, relative to the unconstrained case.

Stage 1. The trust school chooses $n_{1}$ to maximize $Z=\alpha_{1}\left(H_{1}, n_{1}\right)+w(x)$ subject to $H_{1}=n_{1}\left(F_{1}-x\right)+D$, and $n_{1} \leq\left[\Psi\left(y^{T}\right)-\Psi\left(F_{1}\right)\right]$. As argued earlier, it is reasonable to assume that the trust is interested in maximizing average test score and some other social welfare. In so doing it is allowed to decide only on the number of students it will admit. Its spending on education and socially motivated lessons, as the first constraint shows, are financed by charitable donations and tuition fees. The second constraint shows that its students come from families, who are poor but still can afford a small fee. Though the trust school's choice of $n_{1}$ affects the market size of the company-run school as well as the public school, the trust school's objective is such that it is unconcerned about these effects. ${ }^{21}$ Moreover, the second constraint will be non-binding under the scenario we are considering; hence we can disregard it and incorporating the first constraint we write the school's problem as of maximizing $Z=\alpha_{1}\left(n_{1}\left(F_{1}-x\right)+D, n_{1}\right)+w(x)$.

The choice of $n_{1}$ is given by the following first order condition:

$$
Z^{\prime}\left(n_{1}\right)=\frac{\partial \alpha_{1}}{\partial H_{1}}\left(F_{1}-x\right)+\frac{\partial \alpha_{1}}{\partial n_{1}}=0
$$

We assume $F_{1}>x$ to ensure an interior solution. Maximizing $Z$ is equivalent to maximizing $\alpha_{1}$. By increasing $n_{1}$ the trust is able to raise more revenue and therefore able to spend more, which helps to improve the averag score, but on the other hand higher $n_{1}$ also reduces the average score. These two opposing forces are balanced at the optimum. Thus, we have the optimal $n_{1}$, which in turn determines $n_{2}$ and $n_{0}$ and also the company-run school's optimal expenditure and tuition fees.

Insights from our theoretical model: There are several points to note from our simple model.

1. While profit-motivated private schools cater to the high income group, socially motivated organizations, such as the trust-run schools, can provide a choice to the poor. To what extent that choice will be superior to the public school depends on the resources available to the socially motivated school.

2. The actions of the trust schools will have a positive consequence for the students of the public school; the congestion in the public school will be reduced and its average test score will improve.

3. The public school may not necessarily turn into a 'ghetto' of the poor; as shown in this model, due to the presence of the trust school, it may also have a section of the middle class. This diversity may have some positive effect on the students' social attitudes.

\footnotetext{
${ }^{21}$ Implicitly we are assuming that the private school will set $F_{2}$ in excess of $y^{T}$, so that these two schools don't compete, as would be realistic for a country like Nepal.
} 
4. Though the profit-motivated private school is likely to generate a higer expected test score than the trust or the public school, by no means it is guaranteed to be the 'most efficient' producer of test scroes. With better infrastructure it has the best technology to produce high test scores; but because of its profit motive it will also admit more students than socially motivated school (with similar infrastructure) would. In contrast the trust run school would directly maximize the average test score, and thus can be more 'efficient' user of its limited resources.

In Figure 5 we illustrate this point by drawing two sets of expected test score curves $\alpha_{1}$ and $\alpha_{2}$ for the trust school and the profit-oriented company-run school. Suppose the test score functions are such that they can be expressed as a function of expenditure per student, $h(=H / n)$, for any given tution fee and initial capital $K$. These test score functions have a unique maximum, say $\alpha_{1}^{*}$ and $\alpha_{2}^{* *}$, for the trust school and the company-run school respectively at $h_{1}^{*}$ and $h_{2}^{* *}$.

The trust school is choosing $\alpha_{1}^{*}$ in keeping with its social and educational objective, though $\alpha_{1}^{*}$. It is thus an efficient user of its resources. In contrast, the company-run school will choose $h_{2}^{*}$ to maximize profit, though it could choose $h_{2}^{* *}$ that yields highest test score for its given level of infrastructure. In this sense, it is not efficinet. Intuitively, it will admit more students to increase its profit. This deviation from efficiency is exacerbated when the tuition fee cap binds.

5. When the tuition fee cap binds on the company-run school, it is most likely to offer more admissions and at the same time redue expenditure. Overall, it is reasonable to expect that its enrolment will go up, which indirectly reduces public school congestion and thus leads to an improvement in the average test score of the public school; but it comes at the expense of a drop in the average test score of the company-run school.

6. The question of the expansion of trust schools is also interesting. If more funds are provided to the trust school, its expected test score will rise via greater expenditure. However, its enrolement may rise or fall, depending on whether the increased fund helps to ease out the marginal congestion effect. On the other hand, if the fund is provided to improve the infrastructure of the trust school, then it will admit more students, which in turn helps the public school. We record this observation in the following proposition.

Proposition 2. If the fund of the trust school (D), which is used to finance $H_{1}$, goes up, its expected score $\alpha_{1}$ will rise and enrolment may fall or rise. But if the trust school's infrastructure $K_{1}$ is improved, then it will admit more students, and the test score will also rise. In the first (second) case, the public school's test score will fall (rise).

Proof: First consider the case of increasing $D$. That $\alpha_{1}$ will rise is a straight forward implication of the envelope theorem. From the trust school's optimization we get $\partial Z / \partial D=\partial \alpha_{1} / \partial D=\partial \alpha_{1} / \partial H_{1}>0$. For the 
effect on $n_{1}$ derive from (8):

$$
\begin{array}{ll} 
& Z^{\prime \prime}\left(n_{1}\right) \frac{\partial n_{1}}{\partial D}+\frac{\partial Z^{\prime}\left(n_{1}\right)}{\partial D}=0 \\
\text { or } \quad & Z^{\prime \prime}\left(n_{1}\right) \frac{\partial n_{1}}{\partial D}+\frac{\partial^{2} \alpha_{1}}{\partial H_{1}^{2}}\left(F_{1}-x\right)+\frac{\partial^{2} \alpha_{1}}{\partial H_{1} \partial D}=0 \\
\text { or } \quad & \frac{\partial n_{1}}{\partial D}=-\frac{\partial^{2} \alpha_{1}}{\partial H_{1}^{2}}\left(F_{1}-x\right)\left[\frac{1}{Z^{\prime \prime}\left(n_{1}\right)}\right]<0 .
\end{array}
$$

By assumption $\frac{\partial^{2} \alpha_{1}}{\partial H_{1}^{2}}<0$, and it is reasonable to assume $\frac{\partial^{2} \alpha_{1}}{\partial H_{1} \partial D}>0$. The first negative sign reflects the diminishing marginal returns to expenditure, and the second positive return reflects diminishing marginal congestion. Note that $\frac{\partial \alpha_{1}}{\partial n_{1}}<0$ is the marginal congestion effect. With greater resources, the magnitude of the marginal congestion effect $\left(\left|\frac{\partial \alpha_{1}}{\partial n_{1}}\right|\right)$ should fall, i.e. $\frac{\partial}{\partial D}\left|\frac{\partial \alpha_{1}}{\partial n_{1}}\right|<0$. Hence, we assume $\frac{\partial^{2} \alpha_{1}}{\partial H_{1} \partial D}>0$.

Also by the second order condition of maximization $Z^{\prime \prime}\left(n_{1}\right)<0$, and for an interior solution $F_{1}>x$. Then the sign of $\partial n_{1} / \partial D$ critically depends on the relative magnitude of $\frac{\partial^{2} \alpha_{1}}{\partial H_{1}^{2}}$, and $\frac{\partial^{2} \alpha_{1}}{\partial H_{1} \partial D} 0$. So the sign of $\partial n_{1} / \partial D$ is ambiguous.

Now consider an increase in $K_{1}$. As $\alpha_{1}$ rises with $K_{1}$, again by the envelope theorem we can argue that the test score will rise. For the effect on $n_{1}$ consider as before,

$$
\begin{gathered}
Z^{\prime \prime}\left(n_{1}\right) \frac{\partial n_{1}}{\partial K_{1}}+\frac{\partial Z^{\prime}\left(n_{1}\right)}{\partial K_{1}}=0 \\
\text { or } \quad Z^{\prime \prime}\left(n_{1}\right) \frac{\partial n_{1}}{\partial K_{1}}+\frac{\partial^{2} \alpha_{1}}{\partial H_{1} \partial K_{1}}\left(F_{1}-x\right)+\frac{\partial^{2} \alpha_{1}}{\partial n_{1} \partial K_{1}}=0 .
\end{gathered}
$$

Since the last two terms in the above equation are positive, the first term must be negative, and as $Z^{\prime \prime}\left(n_{1}\right)<0$, we must have $\partial n_{1} / \partial K_{1}>0$. QED

In our empirical section we will investigate the households' school choice and the test score differentials between schools. Households with higher incomes are expected to choose high end private schools; but to what extent income plays a role in the choice of a trust school over the public school is of interest. Similarly, the company run private schools are expected to produce higher test scores, but will they be more efficient than the trust schools? Also, will the trust schools always be a beter choice than the public school? These are the questions we will pursue in what follows.

\section{Methodological Issues}

In this section, we develop an empirical strategy to test our central proposition, after controlling for all other possible factors so that the omitted variable bias is minimised. 
Traditional education production functions depict students' test scores as a function of school and child characteristics, plus a random term that reflects measurement error in the test score:

$$
T_{i s}=T\left(s c_{s}, f c_{i}\right)+u_{i s}
$$

where $T_{i s}$ is the test score of child $i$ in school $s, s c_{s}$ is a vector of the characteristics of school $s$, and $f c_{i}$ are the family and child characteristics of child $i$, and $u$ measures random noise in the test scores due to the design of the test and random events that may occur on the day of the test.

Fortunately, in our dataset many of the family and child characteristics are observable; also for school characteristics we have information on some variables such as the percentage of schools with head teacher's full autonomy, students' access to drinking water and toilet and teachers' unionisation. However, still the quality of learning environment induced by the above-mentioned factors is unobservable. So we need to introduce dummy variables, one for the company-run school and another for the trust-run school (keeping the government school as the base). ${ }^{22}$ The significance and size of these two dummy variables would give the relative efficiency of the two types of the private school, in comparison to the public school.

One of our key innovations is the inclusion of school expenditure per student. Arguably, it contributes to students' learning and test scores through its effect of pupils per teacher ratio (as it funds teachers' salaries) as well as use various other teaching and non-teaching inputs (e.g., laboratory, library, sports and other facilities). ${ }^{23}$ In addition we inlude two dummy variables to control for the company- and trust-run private schools (relative to the reference category state schools). These school type dummy vairables are meant to capture differential school specific characteristics as highlighted in Table 1, after controlling for school expenditure per student. The latter may refer to head teacher's autonomy, teachers' efforts, pedagogical methods, incidence of daily homework and weekly tests, all of which may also influence student performance. We also include interactions between school expenditure per student and private school type dummies. This is because the sensitivity of test scores to expenditure per student may not be same in all schools. For instance, being company run a private school may produce much higher test score on average, but also it may (or may not) experience an additional effect from expenditure per student suggesting additional benefits of private management (or the lack of it). Similar argument can be made for the trust school as well. In fact, whether the trust school differs from the company school in this respect is of great interest. In our theoretical section we speculated that the company run school may have the highest expenditure per student, as it caters to the rich, but it may not be the most efficient user of resources as far as the test scores are

\footnotetext{
${ }^{22}$ Otherwise, the unobserved components of $s c_{s}$ and $f c_{i}$ will end up in the error term. This will result in the error term being correlated with the observed school and child characteristics, producing biased results. Needless to if all the school characteristics were observed, the dummy variables would be insignificant.

${ }^{23}$ There is, however, a controversy about the effect of school resources on student achievement in general. Hanushek (1997) concluded that 'there is no strong or consistent relationship between school resources and student performance'. This pessimistic assessment has however been challenged by other US researchers, in particular Krueger (2003), who has criticised Hanushek's methods of selecting studies for review and interpreting them; they provide contrasting evidence of a positive relationship between resources and student attainment, thus justifying a scope for further study. As such there is a need to empirically re-examine the role of school expenditure per student on test scores. We also test the robustness of our expendiure resuls in different ways.
} 
concerned. To the best of our knowledge, incorporating these issues in a school efficiency analysis is a novel attempt in addition to comparing three types of schools.

Two school dummies are $S_{1}$ for trust run schools and $S_{2}$ for company run schools, so that the government schools form the reference category. The school expenditure per student is denoted as $s_{x}$ that covers the running expenses of various teaching and non-teaching inputs in each school type. In order to capture the differential expenditure effect, if any, for each type of private schools, we also construct two interaction terms between school expenditure per student $s_{x}$ on the one hand and school types $S_{1}$ and $S_{2}$ on the other. Accordingly, we can express characteristics of the school attended by the $i$-th child as follows:

$$
s c_{i}=f\left(S_{1 i}, S_{2 i}, s_{x i}, s_{x i} * S_{1 i}, s_{x i} * S_{2 i}\right)
$$

Thus after substituting for $s c_{i}$ from equation (10) into equation (9) for all schools taken together, the total score of the $i$-th child in our sample would be given as follows:

$$
T_{i}=F\left(S_{1 i}, S_{2 i}, s_{x i}, s_{x i} * S_{1 i}, s_{x i} * S_{2 i}, f c_{i}\right)+u_{i s}
$$

Finally for estimation purposes, we approximate equation (11) by the following linearized equation to determine test score of the $i$-th child:

$$
T_{i}=b_{0}+b_{1} S_{1 i}+b_{2} S_{2 i}+b_{3}\left(s_{x i}\right)+b_{4} s_{x i} * S_{1 i}+b_{5} s_{x i} * S_{2 i}+\gamma\left(f c_{i}\right)+u_{i}
$$

The parameters of particular interest to us are the estimated coefficients of the two interaction terms $s_{x i} * S_{1 i}$ and $s_{x i} * S_{2 i}$, which determine the expenditure efficiency of trust-run and company-run private unaided schools (relative to fully funded government funded schools) respectively for a given level of school expenditure per student.

The fact, however, remains that children who attend private schools may differ in unobserved ways from children who attend public schools. For example, parents who send their children to private schools may also help their children, or require them to study more, compared to parents who send their children to public schools. This is the problem of selection bias, which may render simple OLS estimates of (11) to be biased. Hence we need to correct for this selection bias, which is explained in the next sub-section.

\subsection{An Empirical Model}

We start with the school choice equation for the $i$-th child from the $j$-th household residing in the $k$-th VDC (municipality) ${ }^{24}$ as follows:

\footnotetext{
${ }^{24}$ This is identified by the village development committee or VDC for short in our sample, which is the lowest administrative unit for Nepal's local development ministry. Each district has several VDCs, similar to municipalities but with greater publicgovernment interaction and administration
} 


$$
Y_{i j k}^{*}=a_{0}+a_{1} A_{k}+a_{2} W_{i j k}+u_{i j k}
$$

While $Y^{*}$ is unobservable, it is related to an observable variable $S$, which takes a value 1 if the child goes to a company-run school, 2 if the child goes to trust-run school and zero otherwise. ${ }^{25}$ The explanatory variable $A$ takes a value 1 if there is a government school in the $k$-th VDC (i.e., municipality) where the child resides, and 0 otherwise. It can be argued that the access to a government secondary school $A_{k}$ in the municipality is a purely exogenous variable, as the presence of the school in the VDC determined by the government and as such is beyond the control of the child/child's family. Clearly presence of government school in a municipality is closely related to parental school choice and, without much loss of generality, we can therefore treat it as an exogenous determinant of his/her private school choice/enrollment. As high as $92 \%(71 \%)$ of sample VDCs have a governent (private unaided) secondary school in the vicinity so that access to government schools in the community is an essential part of parental school choice decision ${ }^{26}$ The set of variables, $W$, on the other hand, includes a set of individual (e.g. gender, age) and household (e.g. parents' education, income and caste) characteristics relevant for the school choice equation. Given the discrete nature of the dependent variable in equation (13), we use a multinomial logit model to estimate the parameters of equation (13), which are then used to generate the inverse Mill's ratios $M_{G O V}, M_{C O}$ and $M_{T R}$ respectively for government, company and trust-run private school choice in our sample.

At the second stage these inverse Mill's ratios $\left(M_{G O V}, M_{C O}\right.$ and $\left.M_{T R}\right)$ are included in the estimation of equation (11) that determines the total test scores $\mathrm{T}$ (a la Lee 1983). Total test score $\mathrm{T}_{i j k}$ of the $i$-th child from $j$-th family living in $k$-th municipality is determined in terms of school expenditure per student EXP, school type $(C O$ and $T R)$ and also interactions between EXP and school type $(C O$ and $T R)$. In view of the non-linear relationship between standardised test scores and school expenditure per student as seen in Figure 1, we use natural logarithm of the continuous school expenditure per student and denote it by $l E X P$. In doing so, we control for various individual/ family characteristics $(f c)$ and unobserved VDC characteristics $\left(\varphi_{k}\right)$ that account for the unobserved VDC-level variation in public infrastructure, returns to schooling, culture, which could also influence students' test scores.

\footnotetext{
${ }^{25}$ Note that our baseline regressions exclude private aided schools from the analysis; thus the reference category is the fully funded government schools. However, in section 5.5 we relax this restriction and examine if our central hypothesis holds even after we include private aided school as a separate category in school choice equation.

${ }^{26}$ We have also considered the presence of private secondary schools in the municipality as an alternative instrument; but chose not to include it because it is potentially endogenous. Presence of a private school in a community is a matter of preference and lobbying of the local community population. In contrast, presence of a government schools is more likely to be determined by the people outside the community. Further, we find that the local access to a government secondary school does not significantly influence total test scores while that of a private secondary school boosts student standardised test scores. As such we chose acces to local secondary government schools to be an exogenously given identifying variable in the determination of private school choice in the community and not in the 2nd stage test score equation.
} 


$$
\begin{aligned}
T_{i j k}= & \beta_{0}+\beta_{1} C O_{i j k}+\beta_{2} l E X P_{i j k}+\beta_{3} C O_{i j k} * l E X P_{i j k}+\beta_{4} T R_{i j k} \\
& +\beta_{5} T R_{i j k} * l E X P_{i j k}+\beta^{\prime} f c_{i j k}+\beta_{G} M_{G O V i j k}+\beta_{C} M_{C O i j k} \\
& +\beta_{T} M_{T R i j k}+\phi_{k}+e_{i j k}
\end{aligned}
$$

Among individual/family characteristics $(f c)$, equation (14) includes characteristics of the child (male, age at SLC, square of age, if received any peer group help, if no grade repetition in year 9, which is a measure of unobserved ability of the student), those of the family (if any family member is at least a graduate and household expenditure decile). We would also like to run this model for rural urban regions separately. Note that access to a government school variable $A$ is excluded from the test score equation (14), because it is unlikely to have a direct influence on SLC test scores. As such the variable $A$ acts as an identifying restriction for the selection equation. Note that equation (14) is an augmented version of equation (12) in that it controls for the possibility of selection bias in the test score estimates arising from the choice between government and private schools. The latter is reflected in the inclusion of the three Inverse Mill's ratios (IMR) respectively for the government $\left(M_{G O V}\right)$ and two types of private schools $\left(M_{C O}, M_{T R}\right)$ schools (a la Lee, 1983). As such, the estimates of equation (12) would entail the uncorrected estimates while that for equation (14) would yield the corrected estimates of test scores.

We also consider different variants of equation (14) to understand the role of expenditure: (i) first we only retain $l E X P$ and drop the private school dummies and their interactions to $l E X P$ - this enables us to understand to what extent school expenditure per student accounts for school efficiency, other factors remaining unchanged. (ii) Next we augment specification (i) by adding the interactions betweeen $l E X P$ and private school dummies with a view to understand the differential effect of expenditure per student by private school type. Note that in this case we do not include the private schools dummies on their own. (iii) Finally, we also estimate equation (14) that includes $l E X P$, private school dummies and interactions of $l E X P$ with private school dummies. The latter is the most complete specification and hence is our preferred option. The coefficient of particular interest to us is that of the interaction term between the private school type and log expenditure per student, which captures the efficiency of the particular type of private school per unit of school expenditure per student, after controlling for student ability/motivation, household income/education, and/or other unobserved community characteristics that may also influence student test scores.

\subsection{Econometric issues}

Unlike the literature on school resources and student outcome (Hanushek, 1997; Krueger, 2003), our analysis focuses on private unaided schools and hence the case of government allocation of funds to schools does not

arise. Similarly, our case is different from the cases of government schools in the US and the UK (e.g., see 
Steele et al. 2007) as school funding is not a function school performance. Nevertheless head teachers would care about school performance in both trust and company run schools, but more so in trust-run schools.

Accordingly, we consider two possible sources of omitted variables. The first one arises from parental demand for better performing schools. An obvious solution would be to exploit the intra-household variation in school choice and student performance, if possible; but we were unable to do this as we did not have SLC information for all the siblings living in a household. Hence, we control for various parental characteristics including education, income and caste. We also control for the unobserved community level (i.e., VDC) characteristics which determines households' access to different types of schools, as long distance travelling to attend better performing schools is not so common in $\mathrm{Nepal}^{27}$. As an alternative, we also generate a pseudo panel for each individual with test scores across six compulsory SLC subjects with a view to determine the subject fixed effects estimates of standardised test scores. The latter allows us to exploit the variation across subjects test scores (standardised) for a given individual, thus eliminating individual/household level time invariant unobserved factors that may also influence test scores.

A second source of estimation problem arise from schools' (by type) efforts to perform better and thereby investing/recruiting teachers/students of highest ability. The latter may give rise to the potential simultaneity of school expenditure (as well as teachers' salary) per student while determing test scores. While contemporary expenditure per student could be endogenous to test scores in the same year (and may not also fully account for performance as performance improves over time especially during year 9-10), we consider 3 years average expenditure (as well as salary) per student for the period 2002-04 at our access, which is a more long-term measure and may minimise the potential simultaneity while determining SLC test scores.

Note that we were unable to use school fixed effects estimates as we aim to compare and contrast students across private school types - trust or company-run. Hence all regressions control for school expenditure per student (2002-04 average), school type (trust indicated by pua_sch_tr or company schools indicated by pua_sch_co) and also an interactions between the two. So long as we control for pua school type dummies, we account for pua school type level unobserved factors (for example, teacher's quality or characteristics of school management) that may influence student test scores. But there could also be unobserved timevarying school type level factors (e.g., change in school management or change in teachers or non-teaching staff) exclusion of which may give rise to endogeneity bias as well. Given that we have access to 2002-2004 SLC test scores, we account for school type level unobserved time trends as captured by pua_sch_trust*slcyear and pua_sch_co*slcyear (e.g., see Appendix Table A3).

All estimates are clustered around school id-s with a view to minimize any cross-correlations in the error terms for students attending a given school. We obtain the corrected standardised test score estimates not only for the latest survey year 2004, but also for the entire period 2002-2004; in the latter case, we also control for the SLC year fixed effects and also pua school type-level unobserved SLC time trends (e.g., examination related factors overall or school type specific exam related factors) that may also influence SLC

\footnotetext{
${ }^{27}$ as high as $90 \%$ of sample students stayed with parents and another $3 \%$ or so stayed with relatives during year 10
} 
test scores. We check the robustness of our estimates in different ways to eliminate competing explanations: (i) We compare the effect of school expenditure per student by replacing school expenditure per student by teachers' salaries per student and also pupils-teacher ratio. (ii) We also obtain the subject-specific fixed effects estimates of test scores for both 2004, as it allows us to identify the effect of school type on subject level test scores by exploiting the variation in test scores across 6 compulsory subjects for each student and as such better eliminates household/student-level time-invariant omitted factors, if any. (iii) We also try to eliminate the effect of private tuition on standardised test scores as far as possible with a view to establish that our results are not an artefact of differential levels of tuition among students attending these three types of schools.

Means and standard deviations of all explanatory variables are shown in Appendix Table A1.

\section{$5 \quad$ Results}

This section presents and analyses various estimates of school choice and standardised SLC test scores that we obtain from our sample .

\subsection{School choice}

Table 4 summarises the first stage multinomial logit marginal effects estimates of choice of fully funded government and two types of private schools. Columns 1-2 show the estimates for 2004 while columns 3-4 show those for 2002-04. For each period, we show the estimates for company-run (columns 1 and 3), trust-run (columns 2 and 4) private schools (reference category being the government schools).

We use the presence of a fully funded government school in the community as an identifying variable for the school choice equation. It can be argued that the presence of a local government school is exogenously determined by government authority and as such their presence is beyond the control of private households in the community. Further, we find that the local access to a government secondary school does not significantly influence total test scores and hence we chose it to be an exogenously given identifying variable in the determination of private school choice in the community and not in the 2 nd stage test score equation. We also control for individual age, gender, household caste, expenditure, and community dummies (as captured by VDC) to control for unobserved community factors that may also influence school choice. Ceteris paribus, results suggest that the private school enrolment is higher in the presence of a fully funded government school in the community. Further, this effect is statistically significant only for the company run private school and not for the trust-run private schools. In other words, trust schools' admission policy is different, as we have assumed in our theoretical section.

Second, we consider the estimates of household expenditure decile where a higher value of the household expenditure corresponds to significantly higher likelihood of private school choice irrespective of their type 
(i.e., trust or company run schools). In other words, students from richer (i.e., from higher expenditure deciles) households are significantly more likely to choose trust and company run private schools and thereby less likely to choose fully funded government schools. Also note that the marginal effects of household expenditure deciles are quite comparable for choice of trust and company run schools, if both are available in the community, among children from richer households so that they do not reveal any significant preference for company run as opposed to trust-run private schools. In a similar vein, we find that children from Dalit (i.e. lower caste) households, who are also poor, are less likely are more likely to be enrolled in private unaided schools. This pattern tallies with our theoretical model. Individual age or parental education does not turn out to be very important here. Among other variables, boys are significantly more likely to choose private schools irrespective of their type, thus suggesting a male bias in parental school selection. We obtain similar results irrespective of the year under consideration. Results are similar irrespective of whether we consider only 2004 or 2002-04 sample. There is some evidence that children from rural areas are less likely to go to any type of private schools during 2002-04.

\subsection{Private school premium}

We use the first stage multinomial logit estimates (obtained from Table 4 estimates) to generate the inverse Mill's ratios (IMR) for the choice of fully funded government and two types of private schools in our sample for both 2004 and also for the entire 2002-04 periods. Following Lee (1983), we include these three IMRs to determine the standardised test score estimates in the second stage to corrected for the selectivity bias. Table 5 shows the standardised test score estimates in 2004 (columns 1 and 2) and also 2002-04 (columns 3 and 4). Columns (1) and (3) show the uncorrected test score estimates while columns (2) and (4) show the selectivity corrected test score estimates. Since the inverse Mill's ratios for both government and private school choice are statistically significant, we couch our discussion in terms of the corrected estimates of test scores.

We first note that certain individual and household characteristics matter. For instance, male students perform better, and with higher age some increasing returns also set in. Peer help positively affects the test score and conversely ill health hurts. Parents with graduate or higher education are also a facilitating factor. However, household incomes do not matter.

Here is an issue of student's ability. It is very difficult to get data on this. However, we use one piece of information that reflects student's ability to some extent. There are students in our sample who had repeated grade nine. If they did not do this on medical ground (which we have controlled for by the illness variable), then they must be academically weaker students than those who did not repeat grade nine. Column 2 estimates show that those, who did not repeat grade nine, scored $9.11 \%$ standard deviation higher than those who did.

Now we turn our attention to the question of school premium. From the significance of two private school dummy variables, it is clear that there is substantial premium for both types of private schools. Further, 
the coefficient of the trust school dummy is higher than the coefficient of the private school dummy in all four regressions. This is true regardless of the year and whether or not the selectivity bias is corrected. In all cases the trust school is the most efficient of all. The premium for the trust school is even higher when the entire time period 2002-04 is considered (column 4). ${ }^{28}$

Next question is where this efficiency comes from. Is it the learning environment specific to a companyrun or trust-run school (as captured by the private school type dummy), or is it due to the expenditures made by particular private school management toward teaching staff and non-teaching resources (as captured by the interaction between private school dummy and log expenditure per student)? Company-run schools, being profit maximizers, will naturally be efficient users of resources toward providing a more disciplined environment. Trust-run schools, on the other hand, are socially motivated and may be directly geared toward test score maximization. Therefore, when other factors are controlled for, social objective alone may turn a school most efficient. However, we still need to see whether the source of efficieny is something intangible or something measurable like school expenditures per student. We address this next.

\subsection{School expenditure and private school premium}

We add log expenditure per student (3 years' average) to the set of explanatory variables. Table 6 reports these estimates. Columns (1)-(3) show the estimates for 2004 while columns (4)-(6) show those for 2002-04. As the estimates are similar, we can restrict our discussion to 2004. We first see the effect of log expenditure without taking account of the school types in column 1 (and likewise in column 4). This effect is positive as expected. Next, we add the school dummies, but only as interaction with the log expenditure. The direct effect of expenditure immediately disappears; expenditure matters only if it is a trust-run school or a company-run school. That means, in government schools expenditure has no effect. Between the two private schools, the company-run schools seem to be more efficient user of expenditures.

But when we add the private school dummies too in column 3 (most complete specification), the relative superiority of the company-run schools is threatened. The private school dummy is significant, but its interaction with log expenditure loses significance. Just like the government run schools, expenditure does not have any additional impact in company-run schools; it is the learning environment of a company-run school, presumably made possible by expenditure, that counts the most. We know that the company-run schools are better managed with great deal of focus on discipline. The head teachers in these schools have greater autonomy and teachers are less unionsied. These facts alone may contribute a lot to student achievement. $^{29}$

But for the trust school, its dummy does not become significant, while its interaction with log expenditure

\footnotetext{
${ }^{28} \mathrm{~A}$ comparison of the corrected estimates with the corresponding uncorrected ones suggests that the uncorrected estimates tend to under-estimate the private school premium.

${ }^{29}$ A striking difference among the three types of schools in Nepal is the variation in head teacher's autonomy in disciplining teachers. While on average $81 \%$ of company run private school heads have this autonomy, the corresponding proportion falls to $49 \%$ for government schools and $44 \%$ for trust-run private schools. Although we do not explicitly control for these differences, we argue that the two private school dummies would account for these differences in our model.
} 
turns out to be significant. That is to say, the status of being trust-run or government-run does not make any difference to test scores. In principle, both the trust-run and the public school would be sharing a common social objective, and therefore, being trust-run per se may not make any difference. However, the trust school has the advantage of being wastage free. Therefore, it will be able to utilise additional fund much more efficiently than the public school. This is why the expenditure incrementally improves the test score in trust schools (reference category being government schools).

An intriguing possibility is that with the positive incremental effect of expenditure the trust school's test scores will rise, and potentially can exceed the company-run schools' test scores if the expenditure exceeds a critical level. Indeed, using column (3) data we can write the test score equation (suppressing all other variables) for the trust school as $T_{T}=2.101+0.829 x$ where $x$ is the log expenditure per student. For the company-run schools, where expenditure has no incremental effect, the test score equation is simply $T_{C}=3.236$. If $x>1.369$ or equivalently if the annual expenditure per student exceeds 3931.88 Rupees, the trust school will produce higher test scores than the company run schools. According to Table 1, the mean (annual) log expenditure per student is 3.714 Rupees for government schools, 5.263 Rupees for trust schools and 6.966 Rupees for company-run schools. Therefore, a large number of trust schools are likely to be more efficient than the company-run schools. On the other hand, at lower level of expenditures, company-run schools are most efficient.

So long as we control for school type (trust and company-run private schools), we account for school type level unobserved factors that may influence student test scores. For example, teacher's quality, nature of school management that may influence investment in school infrastructure. But there could also be unobserved time-varying school type level factors (e.g., change in school management or change in teachers or non-teaching staff) exclusion of which may give rise to endogeneity bias as well. Given that we have access to 2002-2004 SLC test scores, we further try to account for school type level time trends as captured by pua_sch_trust*slcyear and pua_sch_co*slcyear. These estimates (see Table A3) are also generally compatible with the baseline results shown in columns (4)-(6) of Table 6.

Some policy makers have advocated in favour of low-fee private schools (e.g., Tooley and Dickson, 2003). In an attempt to see how low-fee company schools perform vis-a-vis trust schools in our sample, we next distinguish between low and high fee company schools as follows. A company school is defined low fee if its monthly tuition fee per student in year 10 (the final year before the SLC exam) is less than the first quartile value $(\mathrm{Rp} 850)$ in its distribution. This contrasts with an average monthly tuition fee of $\mathrm{Rp} 1200$ for trust schools and 0 for government schools for year 10. These resutls are summarised in Table $6 \mathrm{~A}$. After controlling for all other factors, we find that expenditure efficiency of trust schools still holds for both 2004 and 2002-04. For 2004, the expenditure interaction term insignificant for low-fee company schools while it is is positive and significant for both trust and low fee schools in 2002-04; however the size of the interaction coefficient is still higher for the trust schools. 


\subsection{Rural-Urban differential in school premium}

But is the hierarchy of private schools (conditional on expenditure) valid in all regions? We try to answer this question by disaggregating the data for rural and urban regions. Table 7 shows that there are interesting differences between the rural and urban parts of Nepal. We run the same set of regressions as shown in Table 6, except that we restrict only to 2004 data. For brievity we just report the findings of the augmented regressions shown in columns 3 (rural) and 6 (urban).

The findings are summarised in Figure 6. As seen in Table 6, here too expenditure does not have any incremental effect on any type of schools except the trust school; this result is robust in both regions. However, the hierarchy between three schools is not same between the ruran and the urban regions. In the rural region, at low levels of expenditure, i.e. log expenditure below 0.899 or equivalently annual expenditure per student less than 2457.90 Rupees, the company-run school is most efficient, followed by the public school and the trust school coming last, as shown in panel $a$ of Figure 6. But as the trust school is able to increase its test score by 1.013 standard deviation for an extra unit of log expenditure, it outperforms the public school from the log expenditure of 0.899 onward, and eventually overtakes the company-run school from $1.522 \log$ expenditure (or equivalently, 4582.347 Rupees) onward. Thus, at higher levels of expenditure the trust school is a clear winner.

In the urban areas, as is evident from column 6 estimates, the public school is always at the bottom. Between the two private schools, the trust-run school overtakes the company-run school at log expenditure of 1.551 or equivalently 4720.128 Rupees onward, which we depict in panel $b$ of Figure 6 . Thus, the ordering of the two types of the private schools is similar between regions.

Here we may recall from Tables 3 and 3A that rural trust schools spend much more per student per year than the rural company-run schools - 6600 Rupees as opposed to 4820 Rupees. In the urban sector, however, the company-run schools spend nearly twice as much (9070 Rupees), while the trust schools spend only 4940. So in the urban areas the company-run schools are able to hold on to its superiority a somewhat longer until the expenditure reaches 4720.18 Rupees.

It is well known that profit motivated schools spend substantially on infrastructure or nonteaching facilities often to attract rich households. These facilities may be valued by well off families for social or other purposes, but they may not contribute much to test scores. It may also be the case that part of the expenditure is directed to monitoring teachers, and enforcing student disciplines; but as these things form the key characteristics of company-run schools their effect is felt only through the school dummy. On the other hand, the trust-run schools are socially motivated and directly aiming at maximizing student achievements. This social objective can be a powerful driver of using every available resource to their best use. Therefore, one may argue that if external funds are to be provided to any of the schools, they should be given to the trust schools, because they are the most efficient user of expenditures.

Role of teacher's salary: We can probe this issue further by considering the spending on teachers' 
salary per student, which constitutes $80 \%$ of the total expenditure in public schools, $70 \%$ in company run schools and $72 \%$ in trust schools. From Table 1 we see that the salary per teacher is highest in public schools (179000 Rupees per year), closely followed by the company run school (165000 Rupees), with the trust schools coming a distant third (117000 Rupees). The company run schools maintain the best pupil teacher ratio (18 pupils per teacher), while the trust schools have 26 pupils per teacher; but the public schools, not unexpectedly, have many more students (42) per teacher. We replace log expenditure per student by $\log$ salary per student and run the same regressions as in Tables 6 and 7. Estimates of these regressions are given in Table A2 in Appendix.

Column 1 of Table A2 reports the estimates for the whole country, while columns 2 and 3 report the estimates for urban and rural sectors respectively. The results are consistent with Tables 6 and 7. Log salary is significant only in trust schools, just as the total expenditure was. Since salary is on average very low in trust schools (34.63\% less than the public school), and therefore, teachers respond much more positively to salary rises. In addition, these teachers are more likely to share the ideology of the school, and they are also likely to be socially motivated. In contrast, teachers in public schools are probably neither motivated, nor easy to monitor (for being unionised). Teachers in private schools, however, are more closely monitored as their Head teahers have greater autonomy in managing them. Therefore, it is not the salary but the Head teacher's role that is more important in private schools. As in Tables 6 and 7, the trust schools come on top at higher levels of log salary, and the company run schools come on top at low levels of log salary. However, in this case, neither in the rural sector (column 2) nor in the urban sector (column 3) the trust school ever comes last. It is as good as the public school, if not better.

\subsection{Ruling out competing explanations}

We now try to rule out some competing arguments for private school premium. The first argument relates to the fact that the expendiure data may not be reliable and that the effect of expenditure on performance could be ambiguous (a la Hanushek, 2003). In order to address these concerns we replace expenditure by pupil-teacher ratio which is a reflection of school expenditure. The second one concerns the unobserved student characteristics, e.g., his/her subject preference (or the lack of it) which may bias our estimates. If students had a particular subject preference, then her test score might be less (or more) affected by the school's teaching. We address this concern by considering subject fixed effects estimates, as we exploit the variation in student performance across six compulsory SLC subjects. Further, there are growing concerns about the use of private tuition in many emerging economies. The students' test scores might be affected by extra-school tuition received, in which case the estimate of school preimum might be upwradly biased. In our main regressions (Tables 5-7) we did not include private tutoring as a separate explanatory variable, because the demand for private tutoring is likely to be correlated with the school's expenditure. If a school spends more on teaching, then its students should feel less compelled to seek outside tutoring. Further there is likely to be a simultaneity between tutoring and test scores. We try to address these concerns in two ways 
- first by explicitly including past private tuition as an explanatory variable for determining standardised SLC test scores, and then by focussing only on those who did not take private tuition (which reduces the sample size). Finally, so far we did not include the case of private aided schools in our analysis, which operate very similarly to government funded schools in many ways, with a view to compare fully funded government schools with trust and company run schools. We shall now relax this assumption with to examine if their inclusion would alter the relative efficiency of trust schools.

\subsubsection{Pupil-Teacher Ratio}

One may argue that the total salary and/or expenditure data may not be reliable. Further there is a debate about the role of expenditure on student performance (Hanushek, 2003; Holmund et al. 2010). In an attempt to address these concerns, we replace expenditure by pupil-teacher ratio, which is effectively an outcome of expenditure incurred by schools and certainly a hard data. Table A4 shows these estimates. Not only do we see the same pattern of efficiency among schools that we have seen earlier, but the superiority of the trust school now becomes unconditional and quantitatively stronger. The dummy variable for the trust school is 3.594 (for 2004 data), while the same for the company run school is 0.75 . So the trust school leads to a more than 4 times standard deviation higher score than the company run school. A higher pupil-teacher ratio reduces test score only in the trust school, very much like the expenditure or teachers' salary exerted their desired effects on the test scores only in trust schools. These estimates further establishes the robustness of the estimates shown in Table 6.

\subsubsection{Subject fixed effects}

Given the richness of our dataset we are able to control for a range of individual, household, community and school characteristics in a rigorous way and minimize the omitted variable bias with a view to identify the causal effect of school choice on performance and also the underlying mechanism. Still there may be a bias from other omitted variables (e.g., parents/students' preferences for better performing schools or student preferences or lack of preference for a subject), which could be correlated with the error term. Given that it is not possible for us to have school-level analysis (as we want to compare/contrast student performance by school types) or student-level panel data for the SLC test scores for non-repetitors, we rearrange the student-level data for 2004 to generate subject-level scores for six compulsory SLC subjects for each student, which can be treated as a pseudo panel. This allows us to exploit the inter-subject variation in standardised SLC test scores for a student and in the process eliminates household/student-level time-invariant omitted factors, if any, affecting test scores.

The subject fixed effects estimates of standardised test scores for 2004 are summarized in Table 8 ; the corresponding school choice estimates for this sample are summarised in Appendix Table A5. As before, we cluster all errors at the school level to minimize any bias arising from the cross-correlation of errors for a given school. Since IMRs are statistically significant, we shall, as before, couch our discussion in terms of 
these corrected estimates. Since there are six compulsory subjects for which we consider the students' test scores, the number of observations is six times that in Table 6 column 3 .

The model we regress is also similar to the one reported in Tables 6 and 7. Column 1 of Table 8 shows the regression for all students; columns 2 and 3 are for the rural and urban regions respectively. As can be seen the pattern of school premium is same as in Table 6 and 7 . The regional patterns are identical to that seen in Table 7. For the national case, the picture closely resembles more like the rural region with the trust school coming last at low levels of expenditure. Therefore, we can argue that our baseline estimates are fairly robust.

\subsubsection{Estimates for students with and without private tutoring}

As is well known, the market for private tutoring is rife in many developing markets and Nepal is no exception. As shown in Table 1, private tutoring is common among all students irrespective of the school type, though its prevalence is about 10 percentage points higher for students in government schools. However, private tuition variable is unlikely to be random in determining test scores and hence we did not directly include it as an explanatory variable in our baseline regressions (Tables 5-7). Here, we examine if inclusion of private tuition alters our estimation results and in this respect we conduct two sets of regressions: first we include a dummy for private tuition undertaken in the past 6 months before the SLC examination for the whole sample (column 1 of Table 9) and secondly we consider only those students who did not take any private tuition (column 3 of Table 9). Of course the number of observations drops drammatically in the second case. Each regression is repeated for subject test scores (cloumns 2 and 4 of Table 9).

A surprising finding of Table 9 is the negative sign of private tuition. One possible explanation for this is that where students take private tuition, the teachers underperform at school and this substitution of class-room effort may hurt the student, in the form of an overall loss of learning. It may also be the case that the students fail to learn independently when they receive extra help, which affects their test score eventually. See Jayachandran (2008) for a similar result obtained in the context of Nepal. ${ }^{30}$ However, for us it is heartening to see that the pattern of school premium remains in tact, which is evident from columns (1) and (2). There is a private school premium, but there is also no clear winner. The trust school dominates at a higher level of expenditure.

Next we exclude all students who had private tuition. Once again the result remains in tact. Interestingly, the picture (as given by column 3) resembles that in panel $a$ of Figure 6, as there are two critical levels of expenditure. Below the first critical level of expenditure the trust school comes last, and above the second critical level of expenditure the trust school comes on top. The government school comes as moderately efficient, particularly at low expenditure levels. This picture is valid also when we study the subject level test scores (column 4). Since in this subsample no students had been tutored privately, the school dummies capture the school's effect much more precisely, and we see that the pattern we saw earlier remains valid.

\footnotetext{
${ }^{30}$ Jayachandran (2008) mainly focusses on private tutoring and in many cases school teachers tutor their own students. She uses the same data as ours.
} 
It is also noteworthy that the company-run school's premimum over and above the state schools is much more pronounced here -1.437 , as compared to that in column 3 of Table 6 (1.135). In fact, the difference between the company-run school and the trust-run school is also widened. Based on the estimates of column 3 , we can write the trust-run school's test score equation as $S_{T}=-2.395+1.607 x$, while the companyrun school's corresponding equation is $S_{C}=1.437$. These two lines cross at $x=2.380$, or equivalently at an expenditure of 10807.19 Rupees. This is significantly higher (more than doubled) than the critical expenditure level we have seen earlier (see the discussion in reference ot Table 7). This suggests that if there were no private tuition provided at all, still we would get the same hierarchy of schools, but for the trust school to come on top its expenditure must rise significantly above its current level. In fact, given the current level of spending, the private school would have maintained its supremacy, if no private tuition were provided. This is consistent also with our primarly observation that the company-run school students receive less private tuition than others.

\subsubsection{Role of private aided schools}

Table 10 summarises the total standardised test score estimates for 2004 and 2002-04 when we include private aided schools as a separate category. The corresponding school choice equation estimates are shown in Appendix Table A6. Evidently the estimated coefficient of private aided school dummy PA_sch is negative (and insignificant) on its own; also the estimated coefficient of PA_sch dummy is insignificant when it is interacted with log expenditure per student. There is thus no evidence to suggest that students graduating from private aided schools perform any better than fully government funded schools (reference category). As before, the company school dummy is significant and positive on its own while the trust school dummy is significant and positive when interacted with log expenditure per student. In other words, our central results are robust to inclusion or exclusion of private aided schools and there is further confirmation that socially motivated trust schools are most expenditure efficient among all types of private schools in our sample.

\section{Concluding Comments}

This paper utilises a unique database from Nepal to determine if there is private school premium, and, if so, to what extent the profit motive contributes to the premium. There are broadly two types of private schools in Nepal: profit-motivated company-run schools and socially motivated trust-run schools. In general, the company-run schools are more expensive, spend more per student, and also generate higher test scores at the school leaving exams. Trust-run schools, though fewer in numbers, seem to be following the company-run schools. Both of course are ahead of the state-run schools. But when we control for individual and household attributes, and focus on the school characteristics, we see a different picture. When the school premium is determined considering only the school type, the trust school comes on top, slightly but distinctly, ahead of the company-run school; both types show substantial premium over and above the government schools. 
Further, when we include the school's expenditure per student, we see that expenditure has incremental effects only in trust-run schools; but that comes with a fall in the trust school's intercept. Consequently, the hierarchy of the three types of school is sensitive to the expenditure level they choose. At high levels of expenditure, the trust schools are the winner, and at low levels of expenditure the company-run schools are the winner. More importantly, the government-run schools are not always the loser. This picture is fairly robust across regions (rural or urban), to considerations of subject fixed effets and to inclusion or exclusion of private aided schools and private tution.

Our analysis gives two important messages. First, socially motivated schools can outperform both profitmotivated schools and the government schools. That is to say, what is seen as pro-poor philanthropic activity can have a strong efficiency dimension. Second, more funds should be directed to such socially motivated schools. Though they are privately organized, by freeing themselves of the profit motive, they would put money where the mouth is; they would spend on educational improvements. A profit-motivated school may decide on its spending strategically, to attract more students, or to improve its sporting and extra-curricular activities, and thus compromise on the efficient use of resources. Government schools, which are supposed to be socially motivated, are hamstrung by wastage and bureaucracy.

There is yet another implication of our study. Education is important for peace building through social inclusion and cohesiveness, especially in a country like Nepal which suffered more than a decade from civil conflicts. Despite huge investment in public schools, the performance of students graduating from public schools significantly lags behind their cohorts from private schools. Socially motivated schools can provide a good alternative, especially to the poor parents, promising a better future for their children, who would have otherwise joined the rebels. Education can be a great peace builder. We hope our findings will inform the donors and policymakers in poor countries that are trying to rebuild themselves after suffering a prolonged armed conflict. 


\section{References}

[1] Beegle, K. and D. Newhouse. 2006. The Effect of School Type on Academic Achievement: Evidence from Indonesia, Journal of Human Resources 41(3):529-557.

[2] Besley, T. and M. Ghatak. 2007. Retailing Public Goods: The Economics of Corporate Social Responsibility, Journal of Public Economics 91:1645-63.

[3] Bhatta. S. 2005. Determinants of Student Performance in the SLC Examinations', SLC study report 13, Ministry of Education and Sport, Nepal.

[4] Caddell, Martha (2007). Private Schools and Political Conflict in Nepal. In: Srivastava, Prachi and Walford, Geoffrey eds. Private Schooling in Less Economically Developed Countries: Asian and African Perspectives. Oxford Studies in Comparative Education. Didcot, UK: Symposium, pp. 187-207.

[5] Carney, S. and M.B. Bista (2009). Community Schooling in Nepal: a genealogy of education reform since 1990. Comparative Education Review, Vol. 53, No. 2, 2009, p. 189-211.

[6] Chudgar, A. and Quin, E. (2012) Relationship Between Private Schooling and Achievement: Results from Rural and Urban India. Economics of Education Review, Vol. 31: 376-90.

[7] Dahejia, R., T. DeLeire, E. Luttmer and J. Mitchell. 2007. The Role of Religious and Social Organizations in the Lives of Disadvantaged Youth, Kennedy School Research Working Paper RWP07-037.

[8] EdInvest (2000), Investment Opportunities in Private Education in India, International Finance Organization, available online at http://www.ifc.org.

[9] Epple, Dennis and Richard E. Romano. 1998. Competition between private and public schools, vouchers and peer-group effects, American Economic Review, 74(1): 33-62

[10] Gautam, R. (2008). Samtaka dhristile niji biddhyalaya [Private schools and equity]. In J. Subedi (Ed.), Kasima niji biddhyalaya [Assessing private schools] (pp. 47-60). Kathmandu: Education Journalists' Group and Action Aid, Nepal.

[11] Government of Nepal: Ministry of Education. (2009). Compendium on education policy in Nepal. Kathmandu.

[12] Hanushek, E. 1997. Assessing the effect of school resources on Student Performance: An update', Educational Evaluation and Policy Analysis, pp. 141-164.

[13] Hanushek, Eric A. 2003. The failure of input-based schooling policies. Economic Journal 113(485): F64-F98.

[14] ILO Report. 2008 'School to Work Transition: Evidence from Nepal', Employment Working Paper No. 10: 2008, ILO Geneva. 
[15] Holmund, H., S. McNally and M. Viarengo. 2010. Does Money Matter for Schools? Economics of Education Review. 29 (6): 1154-1164.

[16] Jayachandran, S. 2008. Incentives to Teach Badly? After-School Tutoring in Developing Countries, mimeo, Stanford University.

[17] Jimenez, E., Lockheed, M., \& Wattanawaha, N. (1988). The relative efficiency of private and public schools: The case of Thailand. The World Bank Economic Review, 2(2), 139-164.

[18] Jimenez, E., \& Lockheed, M. E. (1991). Private versus public education: An international perspective. International Journal of Educational Research, 15(5), 353-497.

[19] Jimenez, E., \& Lockheed, M. E. (1995). Public and private secondary education in developing countries: A comparative study. World Bank discussion papers no. 309. The World Bank, 1818 H Street, NW, Washington, DC 20433.

[20] Jimenez, E., Lockheed, M. E., \& Paqueo, V. (1991). The relative efficiency of private and public schools in developing countries. The World Bank Research Observer, 6(2), 205-218.

[21] Khaniya, T. R. (2007). New horizons in education in Nepal. Kathmandu: Kishor Khaniya.

[22] Kingdon, G. (1996). The quality and efficiency of private and public education: A case-study of urban India. Oxford Bulletin of Economics and Statistics, 58(1), 57-82.

[23] Krueger, A.B. 2003. 'Economic Considerations and Class Size, Economic Journal 113. F34-63.

[24] Lee, L.F. 1983. Generalized Econometric Models with Selectivity, Econometrica 51(2): 507-12.

[25] Liechty, M. (2003) Suitably Modern: Making Middle Class Culture in a New Consumer Society, Princeton, N.J., Princeton University Press.

[26] Muralidharan, K. and Sundraraman, V. (2013), The Aggregate effect of School Choice: Evidence from a Two-Stage Experiment in India, Working Paper, Duke University.

[27] Sharma, U. 2011. Private and Public Schools in Nepal: A Comparative Perspective, unpublished PhD dissertation, University of Minnesota.

[28] Somers, M. A., McEwan, P. J., \& Willms, J. D. (2004) How effective are private schools in Latin America? Comparative Education Review, 48(1), 48-69.

[29] Steele, Fiona, Vignoles, Anna and Jenkins, Andrew (2007) The effect of school resources on pupil attainment: a multilevel simultaneous equation modelling approach. Journal of the Royal Statistical Society, series A, 170 (3), pp. 801-824.

[30] Tooley, J. and P. Dixon. (2003) Private Schools for the Poor: A Case Study from India, CfBT Research and Development, UK. 
Figure 1. Bivariate Kernel Fit of Standardised Total Test Scores Against Log Expenditure Per Student by School Types

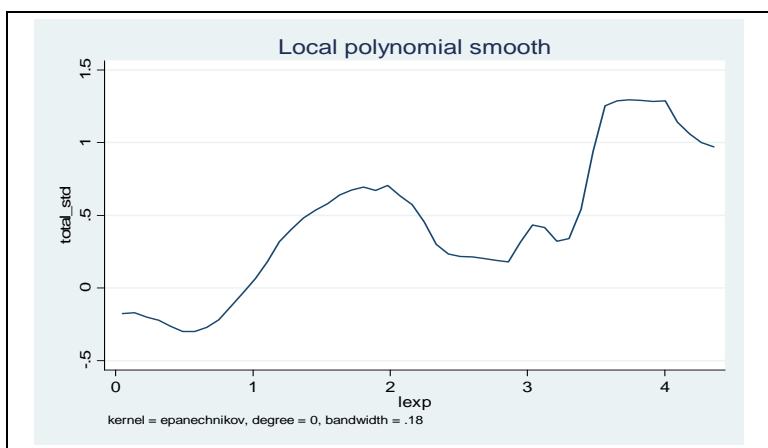

Panel a. All schools

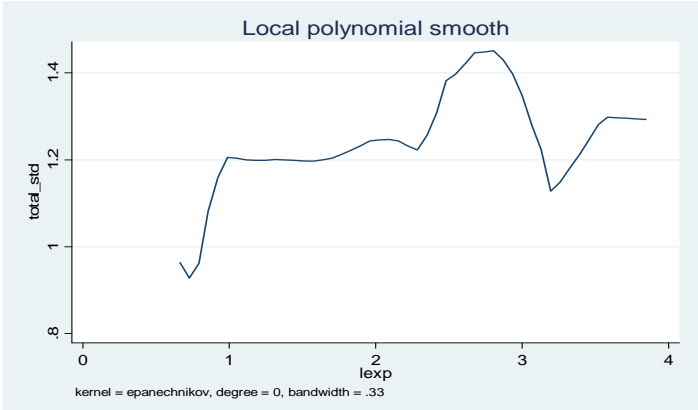

Panel c. All private schools

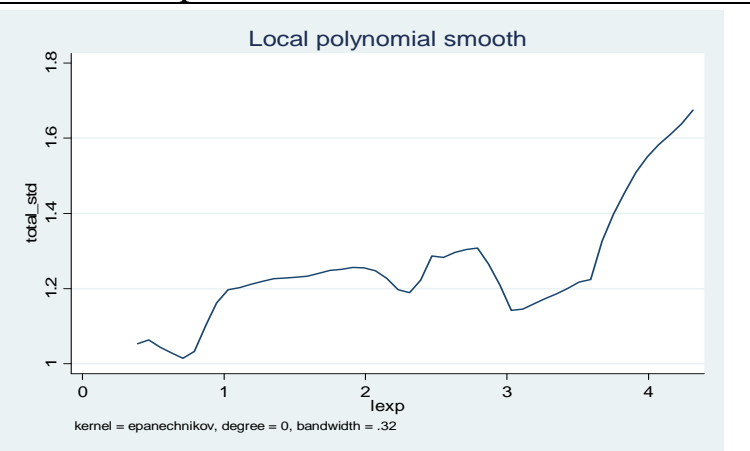

Panel d: All company-run private schools

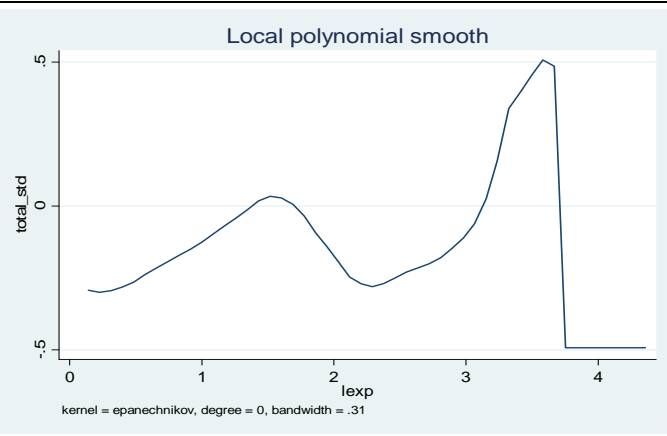

Panel b: All government schools

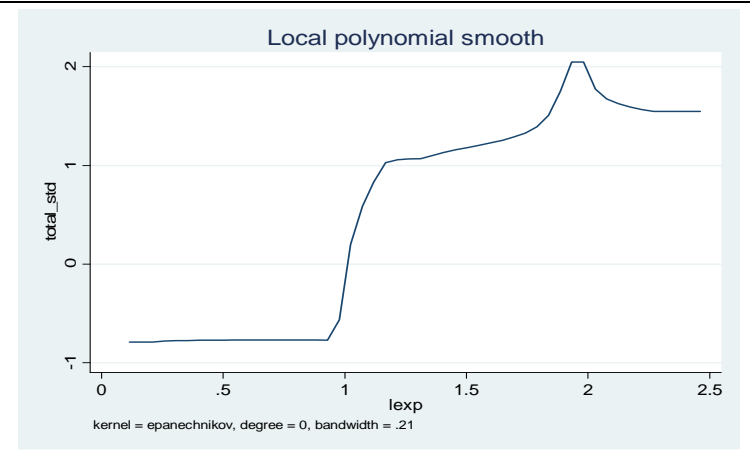

Panel e: All trust-run private schools 
Figure 2. Variation of salary and non-salary expenditure across total expenditure in trust and company schools

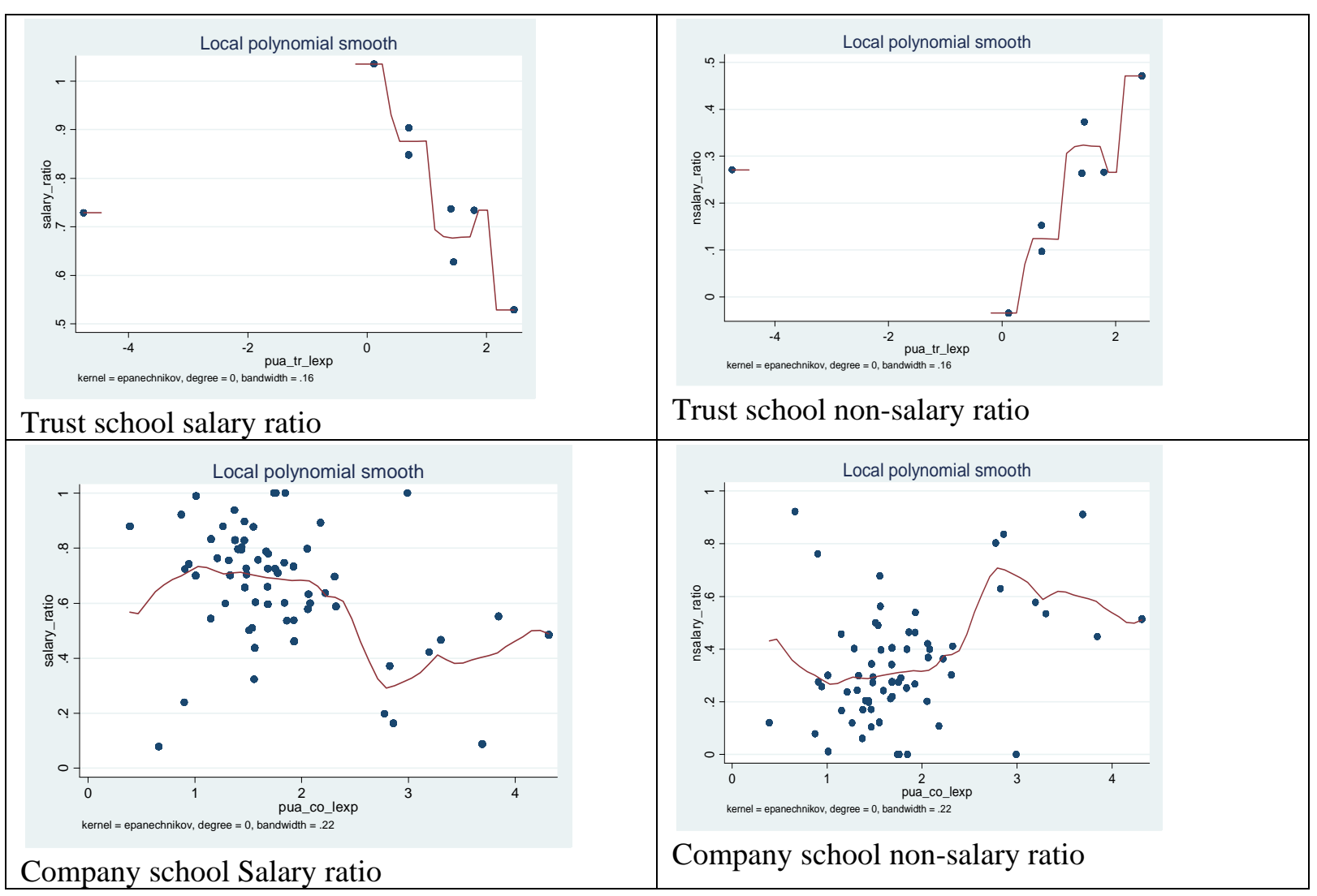

Note: Salary ratio: total salary as a ratio of total expenditure. Non-salary ratio: share of expenditure on non-teaching inputs 


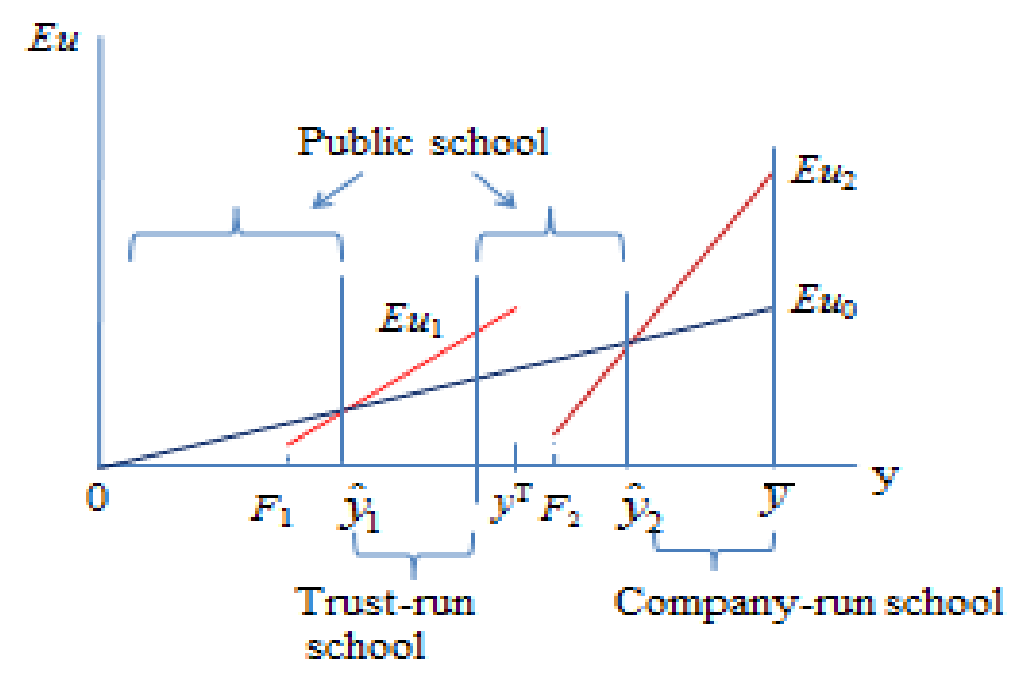

Figure 3: Households' school choice 


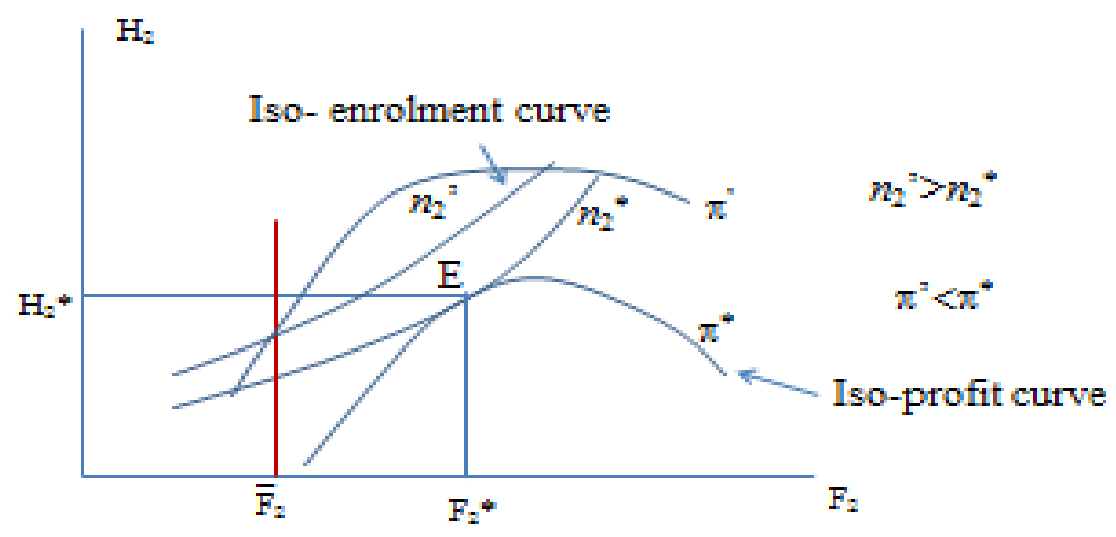

Figure 4: Company-run school's fee and expenditure choice 


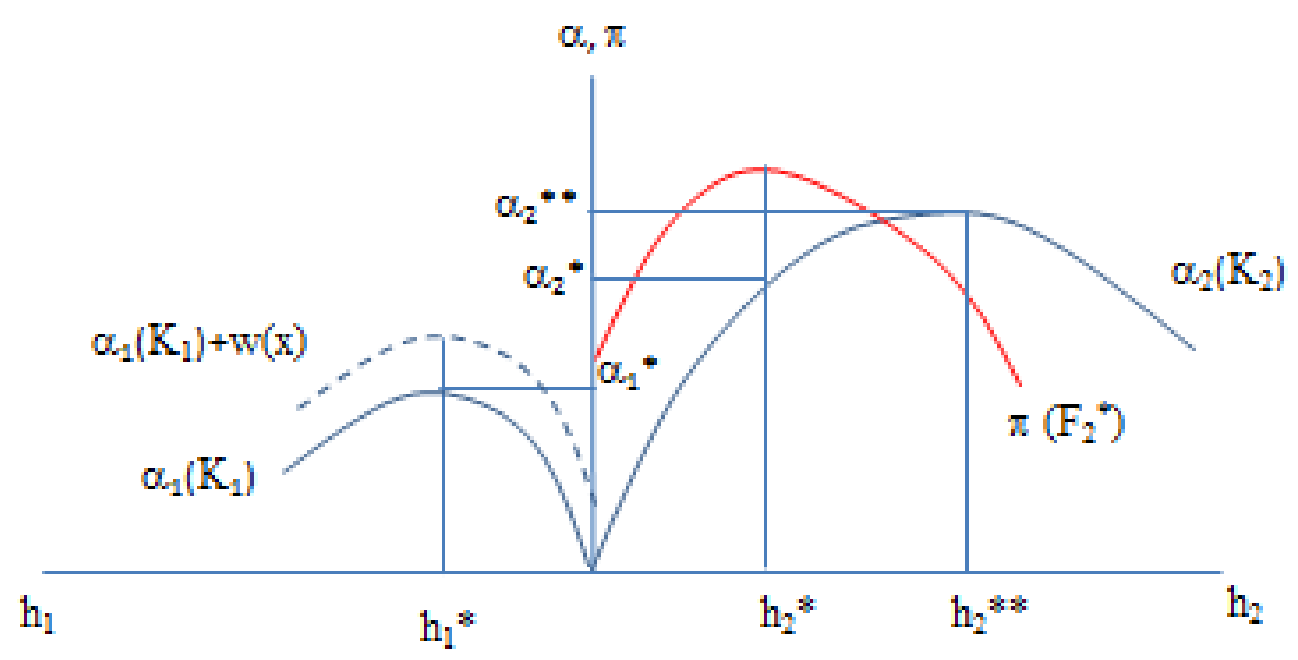

Figure 5: Test score differential 


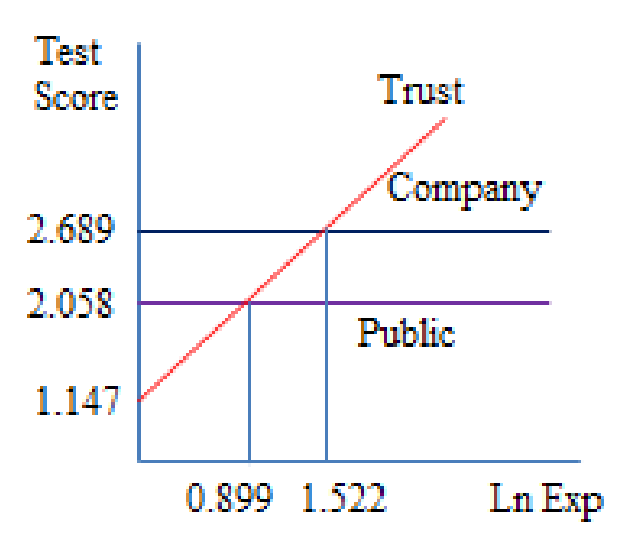

(a) Rural

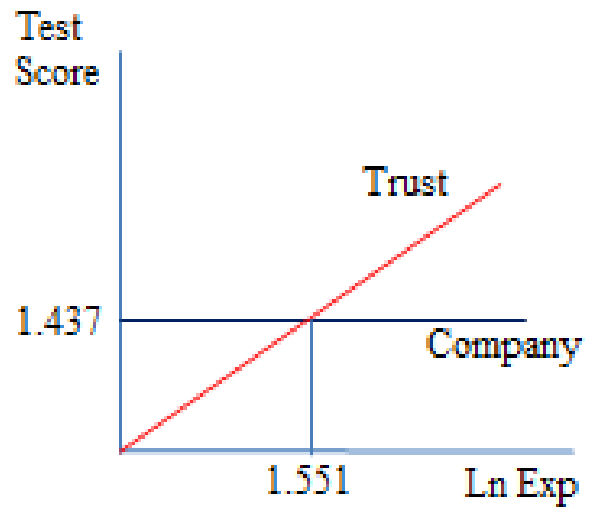

(b) Urban

Figure 6: Role of expenditure 
Table 1. Private school heterogeneity in 2004

\begin{tabular}{llll}
\hline & Govt school & $\begin{array}{l}\text { Trust-run } \\
\text { school }\end{array}$ & $\begin{array}{l}\text { Company-run } \\
\text { school }\end{array}$ \\
\hline & Mean (sd) & Mean (sd) & Mean (sd) \\
\hline Total test scores (unadjusted) & $365(80.12)$ & $466(127.7)$ & $514(83.13)$ \\
Total test scores (standardized) & $-0.18(0.81)$ & $0.82(1.29)$ & $1.31(0.84)$ \\
Total teachers & $18.4(7.03)$ & $26(13.9)$ & $35(29.1)$ \\
Total students & 671 & 628 & 555 \\
Pupils per teacher & $42.1(21)$ & $26.1(14)$ & $18(6.7)$ \\
Head teachers' autonomy: & 0.52 & 0.18 & 0.86 \\
disciplining teachers & & & 0.50 \\
Presence of unionised teachers & 0.96 & 0.88 & 0.14 \\
Teacher never teaches entire pd & 0.34 & 0.16 & 0.153 \\
Share of schools in total schools & 0.82 & 0.027 & 77.4 \\
\% of students being tutored & 90 & 82 & $6.966(12.41)$ \\
privately & & & $165(134.01)$ \\
\hline Expenditure/student ('000 Rp) & $3.714(5.97)$ & $5.263(4.52)$ & $0.72(0.40)$ \\
Av. Salary/teacher & $179(388.4)$ & $117(75.5)$ & 5624 \\
Salary ratio [1] & $0.83(0.20)$ & $0.71(0.14)$ & $119 \%$ \\
School fee/student [2] & 44 & 2516 & \\
School fee (\% of total income) & $2 \%$ & $71 \%$ & \\
\hline Source: Sample data $0 u r$ own & & & \\
\hline
\end{tabular}

Source: Sample data, our own calculation.

[1] Salary ratio is defined as the ratio of salary to total expenditure. In other words, (1-salary ratio) would measure the share of non-salary expenditure in total expenditure.

[2] School fees include fees on admission, readmission, tuition, library, examination and others 
Table 2. Mean comparisons of selected characteristics of company-run and government schools in 2004

\begin{tabular}{llll}
\hline & $\begin{array}{l}\text { Company-run } \\
\text { schools }\end{array}$ & Government schools & T-stat \\
\hline Adjusted expenditure per student (rupee ‘000) & 7.09 & 3.87 & $12.8015^{* * *}$ \\
Teacher’s unionisation (share of total schools) & 0.52 & 0.99 & $-52.3175^{* * *}$ \\
Daily homework (share of total schools) & 0.53 & 0.30 & $13.8191^{* * *}$ \\
Weekly test (share of total schools) & 0.25 & 0.13 & $9.1217^{* * *}$ \\
Autonomy in disciplining (share of total schools) & 0.80 & 0.48 & $19.0492^{* * *}$ \\
Teacher never teaches the entire period & 0.17 & 0.29 & $-6.2542^{* * *}$ \\
Teacher uses lectures only (no student interaction) & 0.05 & 0.07 & $-6.1250^{* * *}$ \\
Total SLC scores (raw scores) & 501.384 & 391.3691 & $31.6858^{* * *}$ \\
Total standardized SLC scores & 1.19 & 0.075 & $31.6858^{* * *}$ \\
Father’s education (yrs) & 5.62 & 4.22 & $17.0251^{* * *}$ \\
Mother’s education (yrs) & 3.44 & 2.44 & $15.3469^{* * *}$ \\
Household expenditure decile & 7.99 & 5.64 & $23.8978^{* * *}$ \\
\hline
\end{tabular}


Table 3. Company-run private schools - rural and urban

\begin{tabular}{llll}
\hline & Urban & Rural & T-stat \\
\hline Total SLC scores & 518.08 & 455.07 & $14.2146^{* * *}$ \\
Adjusted total SLC scores & 1.45 & 1.06 & $8.8931 * * *$ \\
Adjusted expenditure per student (rp000) & 9.07 & 4.82 & $14.2148^{* * *}$ \\
Salary share of total expenditure & 0.77 & 0.83 & $-4.6108^{* * *}$ \\
Pupils per teacher & 22 & 19 & $7.4588^{* * *}$ \\
Share of unionised teachers & 0.63 & 0.58 & $2.0146^{* *}$ \\
Autonomy in disciplining (share of total schools) & 0.79 & 0.71 & $4.0651^{* * *}$ \\
Teacher never teaches the entire period & 0.08 & 0.05 & 1.6698 \\
Teacher uses lectures only (no student interaction) & 0.049 & 0.047 & 0.4335 \\
Parent-teacher association & 0.11 & 0.099 & 0.6632 \\
School has library & 0.94 & 0.84 & $9.5531^{* * *}$ \\
School has science lab & 0.92 & 0.88 & $3.7275^{* * *}$ \\
School has access to drinking water & 0.86 & 0.78 & $5.8172^{* * *}$ \\
School has access to toilet & 0.91 & 0.80 & $9.2773^{* * *}$ \\
\hline
\end{tabular}

Note: ${ }^{* * *}$ denotes that the variable is significant at $1 \%$ or lower level. School expenditure is expressed in rupees ('000) at 2000 prices. 
Table 3A. Trust-run private schools - rural and urban

\begin{tabular}{|c|c|c|c|}
\hline & Urban & Rural & T-stat \\
\hline Total SLC scores & 482 & 394 & $4.3309 * * *$ \\
\hline Adjusted total SLC scores & 0.99 & 0.10 & $4.3309 * * *$ \\
\hline $\begin{array}{l}\text { Adjusted expenditure per student } \\
\text { (rupee '000) }\end{array}$ & 4.94 & 6.60 & -1.4064 \\
\hline Salary share of total expenditure & 0.68 & 0.66 & 0.5060 \\
\hline Number of pupils per teacher & 24 & 30.5 & $-2.8805 * * *$ \\
\hline Share of unionised teachers & 0.82 & 0.54 & $4.0561 * * *$ \\
\hline $\begin{array}{l}\text { Autonomy in disciplining (share of } \\
\text { total schools) }\end{array}$ & 0.46 & 0.43 & 0.2870 \\
\hline Teacher never teaches the entire period & 0.10 & 0.11 & 0.1962 \\
\hline $\begin{array}{l}\text { Teacher uses lectures only (no student } \\
\text { interaction) }\end{array}$ & 0.06 & 0.03 & $1.7073^{*}$ \\
\hline Parent-teacher association & 0.29 & 0.04 & $3.5444 * *$ \\
\hline \multicolumn{4}{|l|}{ Access to school library } \\
\hline Access to science lab & 0.79 & 0.83 & -0.5207 \\
\hline Access to drinking water & 0.93 & 0.96 & -0.7139 \\
\hline Access to toilet & 0.85 & 0.96 & $-1.8847 *$ \\
\hline
\end{tabular}

Note: ${ }^{* * *}$ denotes that the variable is significant at $1 \%$ or lower level. School expenditure is expressed in rupees ('000) at 2000 prices. 
Table 4. Multinomial Logit Estimates of School Choice

\begin{tabular}{|c|c|c|c|c|}
\hline \multirow[b]{2}{*}{ Variables } & \multicolumn{2}{|c|}{2004} & \multicolumn{2}{|c|}{ 2002-04 } \\
\hline & $\begin{array}{l}\text { (1) Company } \\
\text { run }\end{array}$ & $\begin{array}{l}\text { (2) Trust- } \\
\text { run }\end{array}$ & $\begin{array}{l}\text { (3) Company } \\
\text { run }\end{array}$ & (4) Trust-run \\
\hline \multirow[t]{2}{*}{ Male } & $0.605^{* * *}$ & $0.757 * * *$ & $0.486 * * *$ & 0.304 \\
\hline & $(0.144)$ & $(0.260)$ & $(0.146)$ & $(0.207)$ \\
\hline \multirow[t]{2}{*}{ Age at SLC } & -0.143 & 1.247 & -0.0693 & 4.711 \\
\hline & $(0.110)$ & $(3.681)$ & $(0.0882)$ & $(3.461)$ \\
\hline \multirow[t]{2}{*}{ Square of age at SLC } & 0.00117 & -0.0471 & 0.000523 & -0.141 \\
\hline & $(0.000970)$ & $(0.111)$ & $(0.000779)$ & $(0.105)$ \\
\hline \multirow{2}{*}{$\begin{array}{l}\text { An adult member is at least } \\
\text { graduate }\end{array}$} & -0.0325 & -0.0463 & -0.126 & 0.0291 \\
\hline & $(0.122)$ & $(0.258)$ & $(0.109)$ & $(0.146)$ \\
\hline \multirow[t]{2}{*}{ Household expenditure decile } & $0.406 * * *$ & $0.393^{*}$ & $0.418 * * *$ & $0.398 * *$ \\
\hline & $(0.0419)$ & $(0.206)$ & $(0.0367)$ & $(0.172)$ \\
\hline \multirow[t]{2}{*}{ Janajati } & 0.229 & $-1.106 * *$ & 0.236 & $-1.228 * *$ \\
\hline & $(0.223)$ & $(0.556)$ & $(0.207)$ & $(0.542)$ \\
\hline \multirow[t]{2}{*}{ Dalit } & $-0.989 * * *$ & -1.067 & $-0.586 *$ & -0.868 \\
\hline & $(0.349)$ & $(0.694)$ & $(0.302)$ & $(0.629)$ \\
\hline \multirow[t]{2}{*}{ Chhetri } & 0.262 & -0.103 & 0.254 & -0.138 \\
\hline & $(0.212)$ & $(0.343)$ & $(0.181)$ & $(0.324)$ \\
\hline \multirow[t]{2}{*}{ Govt sec. school in VDC } & $1.881 * * *$ & 0.715 & $1.921 * * *$ & 0.801 \\
\hline & $(0.683)$ & $(0.972)$ & $(0.675)$ & $(0.960)$ \\
\hline \multirow[t]{2}{*}{ Intercept } & $-3.401^{*}$ & -14.09 & $-4.234 * * *$ & -45.01 \\
\hline & (1.929) & (31.75) & $(1.622)$ & (29.39) \\
\hline SLC year Fixed Effect (FE) & No & No & Yes & Yes \\
\hline VDC FE & Yes & Yes & Yes & Yes \\
\hline Log-Likelihood & -1665.5822 & & -3114.7208 & \\
\hline Observations & 4619 & 4619 & 7977 & 7977 \\
\hline
\end{tabular}

Reference category: fully funded government schools 
Table 5. Private school premium for total standardised test scores

\begin{tabular}{|c|c|c|c|c|}
\hline & (1) & $(2)$ & (3) & $(4)$ \\
\hline Variables & 2004 & 2004 & $2002-04$ & 2002-04 \\
\hline \multirow[t]{2}{*}{ Male } & $0.225 * * *$ & $0.152 * * *$ & $0.230 * * *$ & $0.201 * * *$ \\
\hline & $(0.0340)$ & $(0.0551)$ & $(0.0339)$ & $(0.0428)$ \\
\hline \multirow[t]{2}{*}{ Age at SLC } & $-0.201 * * *$ & $-0.181 * * *$ & $-0.207 * * *$ & $-0.187 * * *$ \\
\hline & $(0.0211)$ & $(0.0250)$ & $(0.0173)$ & $(0.0189)$ \\
\hline \multirow[t]{2}{*}{ Square of age at SLC } & $0.00174 * * *$ & $0.00156 * * *$ & $0.00178 * * *$ & $0.00142 * * *$ \\
\hline & $(0.000185)$ & $(0.000219)$ & $(0.000152)$ & $(0.000210)$ \\
\hline \multirow[t]{2}{*}{ Has any health problems } & $-0.612 * * *$ & $-0.613 * * *$ & $-0.617 * * *$ & $-0.616 * * *$ \\
\hline & $(0.0439)$ & $(0.0429)$ & $(0.0370)$ & $(0.0366)$ \\
\hline \multirow[t]{2}{*}{ Received peer help } & $0.185 * * *$ & $0.181^{* * *}$ & $0.207 * * *$ & $0.208 * * *$ \\
\hline & $(0.0476)$ & $(0.0483)$ & $(0.0334)$ & $(0.0337)$ \\
\hline \multirow[t]{2}{*}{ No grade repetition in year 9} & 0.0851 & $0.0911 *$ & $0.0878 *$ & 0.0781 \\
\hline & $(0.0523)$ & $(0.0493)$ & $(0.0506)$ & $(0.0501)$ \\
\hline \multirow[t]{2}{*}{ One parent is at least graduate } & $0.0952 * *$ & 0.0651 & $0.0784 * *$ & $0.0858 * * *$ \\
\hline & $(0.0415)$ & $(0.0397)$ & $(0.0328)$ & $(0.0322)$ \\
\hline \multirow[t]{2}{*}{ Household expenditure decile } & $0.0206 * *$ & -0.0252 & $0.0256 * * *$ & -0.00516 \\
\hline & $(0.00867)$ & $(0.0217)$ & $(0.00646)$ & $(0.0167)$ \\
\hline \multirow[t]{2}{*}{ Company-run school (CO) } & $1.093 * * *$ & $1.030 * * *$ & $1.043^{* * *}$ & $1.033 * * *$ \\
\hline & $(0.136)$ & $(0.141)$ & $(0.105)$ & $(0.103)$ \\
\hline \multirow[t]{2}{*}{ Trust-run school (TR) } & $1.153 * * *$ & $1.042 * * *$ & $1.133 * * *$ & $1.168 * * *$ \\
\hline & $(0.209)$ & $(0.182)$ & $(0.181)$ & $(0.185)$ \\
\hline \multirow[t]{2}{*}{ Intercept } & $2.354 * * *$ & $2.234 * * *$ & $2.398 * * *$ & $2.902 * * *$ \\
\hline & $(0.324)$ & $(0.325)$ & $(0.279)$ & $(0.286)$ \\
\hline Inverse Mill’s Ratio (IMR) & No & Yes & No & Yes \\
\hline VDC FE & Yes & Yes & Yes & Yes \\
\hline SLC Year FE & No & No & Yes & Yes \\
\hline Observations & 3739 & 3739 & 6434 & 6434 \\
\hline R-squared & 0.444 & 0.452 & 0.425 & 0.431 \\
\hline
\end{tabular}


Table 6. School expenditure and private school premium for total standardised SLC scores

\begin{tabular}{|c|c|c|c|c|c|c|}
\hline Variables & $\begin{array}{c}(1) \\
2004\end{array}$ & $\begin{array}{c}(2) \\
2004 \\
\end{array}$ & $\begin{array}{c}(3) \\
2004 \\
\end{array}$ & $\begin{array}{c}(4) \\
2002-04 \\
\end{array}$ & $\begin{array}{c}5) \\
2002-04 \\
\end{array}$ & $\begin{array}{c}6) \\
2002-04 \\
\end{array}$ \\
\hline Log exp. per student (LEXP) & $\begin{array}{c}0.251^{* * * *} \\
(0.0888)\end{array}$ & $\begin{array}{l}-0.0156 \\
(0.0776)\end{array}$ & $\begin{array}{c}0.0533 \\
(0.0733)\end{array}$ & $\begin{array}{c}0.287 * * * \\
(0.0830)\end{array}$ & $\begin{array}{l}0.00481 \\
(0.0696)\end{array}$ & $\begin{array}{c}0.0662 \\
(0.0667)\end{array}$ \\
\hline Company-run school (CO) & & & $\begin{array}{c}1.135 * * * \\
(0.250)\end{array}$ & & & $\begin{array}{c}0.973 * * * \\
(0.212)\end{array}$ \\
\hline Trust-run school (TR) & & & $\begin{array}{l}-0.690 \\
(0.451)\end{array}$ & & & $\begin{array}{l}-0.348 \\
(0.340)\end{array}$ \\
\hline CO*LEXP & & $\begin{array}{c}0.563 * * * \\
(0.0807)\end{array}$ & $\begin{array}{c}-0.0186 \\
(0.113)\end{array}$ & & $\begin{array}{c}0.525 * * * \\
(0.0692)\end{array}$ & $\begin{array}{l}0.0215 \\
(0.101)\end{array}$ \\
\hline TR*LEXP & & $\begin{array}{c}0.519 * * * \\
(0.0635)\end{array}$ & $\begin{array}{c}0.829 * * * \\
(0.206)\end{array}$ & & $\begin{array}{c}0.517 * * * \\
(0.0483)\end{array}$ & $\begin{array}{c}0.659 * * * \\
(0.158)\end{array}$ \\
\hline Intercept & $\begin{array}{c}1.621^{* * * *} \\
(0.469)\end{array}$ & $\begin{array}{c}2.063^{* * *} \\
(0.405)\end{array}$ & $\begin{array}{c}2.101^{* * *} \\
(0.396)\end{array}$ & $\begin{array}{c}2.317 * * * \\
(0.363)\end{array}$ & $\begin{array}{c}2.824^{* * *} \\
(0.301)\end{array}$ & $\begin{array}{c}2.786^{* * *} * \\
(0.299)\end{array}$ \\
\hline Other control variables[1] & Yes & Yes & Yes & Yes & Yes & Yes \\
\hline VDC FE & Yes & Yes & Yes & Yes & Yes & Yes \\
\hline SLC Year FE & No & No & No & Yes & Yes & Yes \\
\hline IMR & Yes & Yes & Yes & Yes & Yes & Yes \\
\hline Observations & 3739 & 3739 & 3739 & 6434 & 6434 & 6434 \\
\hline R-squared & 0.349 & 0.443 & 0.460 & 0.327 & 0.420 & 0.435 \\
\hline
\end{tabular}

Robust standard errors in parentheses; other variables are as in Table 5. $* * * \mathrm{p}<0.01,{ }^{* *} \mathrm{p}<0.05, * \mathrm{p}<0.1$

[1] Other control variables are as in Table 5 column (2). 
Table 6A. Total standardised test score estimates with control for low/high fee company schools

\begin{tabular}{lcc}
\hline & $(1)$ & $(2)$ \\
Variables & 2004 & $2002-04$ \\
\hline & & \\
Log exp. per student (LEXP) & -0.0979 & -0.0702 \\
& $(0.0659)$ & $(0.0550)$ \\
Trust-run school (TR) & -0.148 & -0.0381 \\
& $(0.604)$ & $(0.495)$ \\
High fee CO school & $1.164^{* * *}$ & $1.011^{* * *}$ \\
& $(0.284)$ & $(0.228)$ \\
Low fee CO school & 0.252 & 0.175 \\
& $(0.468)$ & $(0.325)$ \\
TR*LEXP & $0.699 * * *$ & $0.604^{* * *}$ \\
& $(0.257)$ & $(0.213)$ \\
High fee CO school*LEXP & 0.0408 & 0.0757 \\
& $(0.120)$ & $(0.101)$ \\
Low fee CO school*LEXP & 0.355 & $0.395^{* *}$ \\
& $(0.246)$ & $(0.161)$ \\
Constant & $2.413^{* * *}$ & $2.411^{* * *}$ \\
& $(0.327)$ & $(0.276)$ \\
Other control variables & Yes & Yes \\
VDC FE & Yes & Yes \\
SLC year FE & No & Yes \\
IMR & Yes & Yes \\
Observations & 4,586 & 7,894 \\
R-squared & 0.429 & 0.412 \\
\hline
\end{tabular}

Robust standard errors are in parentheses; ${ }^{* * *} \mathrm{p}<0.01,{ }^{* *} \mathrm{p}<0.05,{ }^{*} \mathrm{p}<0.1$. Other control variables are as in Table 5. 
Table 7. Total standardised test scores by regions (rural/urban): 2004 results

\begin{tabular}{|c|c|c|c|c|c|c|}
\hline Variables & $\begin{array}{c}(1) \\
\text { Rural } \\
\end{array}$ & $\begin{array}{c}(2) \\
\text { Rural } \\
\end{array}$ & $\begin{array}{c}(3) \\
\text { Rural } \\
\end{array}$ & $\begin{array}{c}\text { (4) } \\
\text { Urban }\end{array}$ & $\begin{array}{c}(5) \\
\text { Urban } \\
\end{array}$ & $\begin{array}{c}\text { (6) } \\
\text { Urban } \\
\end{array}$ \\
\hline Log exp. per student (LEXP) & $\begin{array}{c}0.233^{* * *} \\
(0.0845)\end{array}$ & $\begin{array}{c}0.108 \\
(0.0805)\end{array}$ & $\begin{array}{c}0.123 \\
(0.0812)\end{array}$ & $\begin{array}{c}0.291 * * \\
(0.136)\end{array}$ & $\begin{array}{c}-0.275^{* *} \\
(0.130)\end{array}$ & $\begin{array}{c}-0.0566 \\
(0.109)\end{array}$ \\
\hline Company-run school (CO) & & & $\begin{array}{c}0.631^{* * *} \\
(0.217)\end{array}$ & & & $\begin{array}{c}1.437 * * * \\
(0.350)\end{array}$ \\
\hline Trust-run school (TR) & & & $\begin{array}{c}-0.911^{*} \\
(0.525)\end{array}$ & & & $\begin{array}{l}-0.904 \\
(0.661)\end{array}$ \\
\hline CO*LEXP & & $\begin{array}{c}0.524 * * * \\
(0.0905)\end{array}$ & $\begin{array}{c}0.181 \\
(0.138)\end{array}$ & & $\begin{array}{c}0.657 * * * \\
(0.0930)\end{array}$ & $\begin{array}{c}-0.0910 \\
(0.159)\end{array}$ \\
\hline TR*LEXP & & $\begin{array}{c}0.583 * * * \\
(0.133)\end{array}$ & $\begin{array}{c}1.013^{* * *} \\
(0.256)\end{array}$ & & $\begin{array}{c}0.574 * * * \\
(0.0674)\end{array}$ & $\begin{array}{c}0.926 * * * \\
(0.289)\end{array}$ \\
\hline Intercept & $\begin{array}{c}1.771 * * * \\
(0.461)\end{array}$ & $\begin{array}{c}2.034^{* * *} \\
(0.434)\end{array}$ & $\begin{array}{c}2.058 * * * \\
(0.432)\end{array}$ & $\begin{array}{c}-2.290 \\
(5.367)\end{array}$ & $\begin{array}{c}2.461 \\
(3.767)\end{array}$ & $\begin{array}{c}3.534 \\
(3.730)\end{array}$ \\
\hline Other control variables[1] & Yes & Yes & Yes & Yes & Yes & Yes \\
\hline VDC FE & Yes & Yes & Yes & Yes & Yes & Yes \\
\hline IMR & Yes & Yes & Yes & Yes & Yes & Yes \\
\hline Observations & 2499 & 2499 & 2499 & 1239 & 1239 & 1239 \\
\hline R-squared & 0.309 & 0.361 & 0.365 & 0.354 & 0.522 & 0.559 \\
\hline
\end{tabular}

Robust standard errors in parentheses; *** $\mathrm{p}<0.01$, ** $\mathrm{p}<0.05$, * $\mathrm{p}<0.1$

[1] Other control variables are as in Table 5 column (2). 
Table 8. 2004 Subject-level standardised test scores estimates using subject fixed effects

\begin{tabular}{lccc}
\hline & & & \\
Variables & $(1)$ All & $(2)$ Rural & $(3)$ Urban \\
\hline & & & \\
Log exp. per student (LEXP) & 0.0450 & 0.0840 & 0.0773 \\
& $(0.0609)$ & $(0.0671)$ & $(0.0875)$ \\
Company-run school (CO) & $0.930^{* * *}$ & $0.490^{*}$ & $1.315^{* * *}$ \\
& $(0.208)$ & $(0.255)$ & $(0.259)$ \\
Trust-run school (TR) & $-0.652^{*}$ & $-1.065^{* * *}$ & -0.770 \\
& $(0.350)$ & $(0.256)$ & $(0.496)$ \\
CO*LEXP & -0.0604 & 0.0451 & -0.223 \\
& $(0.0995)$ & $(0.150)$ & $(0.145)$ \\
TR*LEXP & $0.641^{* * *}$ & $0.845^{* * *}$ & $0.712^{* * *}$ \\
& $(0.164)$ & $(0.151)$ & $(0.231)$ \\
Intercept & $1.576^{* * *}$ & $1.366^{* * *}$ & -0.913 \\
& $(0.286)$ & $(0.329)$ & $(3.147)$ \\
Other control variables & Yes & Yes & Yes \\
IMR & Yes & Yes & Yes \\
Subject FE & Yes & Yes & Yes \\
VDC FE & Yes & Yes & Yes \\
Observations & 22463 & 15034 & 7429 \\
R-squared & 0.167 & 0.127 & 0.207 \\
\hline
\end{tabular}

Robust standard errors in parentheses; ${ }^{* * *} \mathrm{p}<0.01,{ }^{* *} \mathrm{p}<0.05,{ }^{*} \mathrm{p}<0.1$; other control variables are as in Table 5. 
Table 9. Effect of tutoring: Standardised test score estimates (total and subject-level)

\begin{tabular}{|c|c|c|c|c|}
\hline & \multicolumn{2}{|c|}{ Full sample } & \multicolumn{2}{|c|}{ Students without tutoring } \\
\hline Variables & (1) Total & $\begin{array}{l}\text { (2) Subject- } \\
\text { level }\end{array}$ & (3) Total & $\begin{array}{l}\text { (4) Subject- } \\
\text { level }\end{array}$ \\
\hline Any tutoring & $\begin{array}{l}-0.168 * * \\
(0.0740)\end{array}$ & $\begin{array}{l}-0.141^{* *} \\
(0.0606)\end{array}$ & - & - \\
\hline Log exp. per student (LEXP) & $\begin{array}{c}0.0454 \\
(0.0708)\end{array}$ & $\begin{array}{c}0.0428 \\
(0.0612)\end{array}$ & $\begin{array}{l}-0.0799 \\
(0.123)\end{array}$ & $\begin{array}{l}-0.0545 \\
(0.106)\end{array}$ \\
\hline Company-run school (CO) & $\begin{array}{c}1.093 * * * \\
(0.232)\end{array}$ & $\begin{array}{c}0.899 * * * \\
(0.199)\end{array}$ & $\begin{array}{c}1.437 * * \\
(0.718)\end{array}$ & $\begin{array}{l}1.205 * * \\
(0.551)\end{array}$ \\
\hline Trust-run school (TR) & $\begin{array}{l}-0.779 \\
(0.482)\end{array}$ & $\begin{array}{l}-0.670^{*} \\
(0.344)\end{array}$ & $\begin{array}{c}-2.395 * * * \\
(0.535)\end{array}$ & $\begin{array}{l}-0.970 * \\
(0.568)\end{array}$ \\
\hline CO*LEXP & $\begin{array}{c}-0.00340 \\
(0.111)\end{array}$ & $\begin{array}{l}-0.0511 \\
(0.0956)\end{array}$ & $\begin{array}{l}0.0413 \\
(0.441)\end{array}$ & $\begin{array}{c}-0.0264 \\
(0.347)\end{array}$ \\
\hline TR*LEXP & $\begin{array}{c}0.860 * * * \\
(0.216)\end{array}$ & $\begin{array}{c}0.645 * * * \\
(0.162)\end{array}$ & $\begin{array}{c}1.607 * * * \\
(0.282)\end{array}$ & $\begin{array}{c}0.868 * * * \\
(0.288)\end{array}$ \\
\hline Intercept & $\begin{array}{c}2.559 * * * \\
(0.393)\end{array}$ & $\begin{array}{c}1.679 * * * \\
(0.289)\end{array}$ & $\begin{array}{c}2.848 \\
(8.980)\end{array}$ & $\begin{array}{l}-1.182 \\
(6.869)\end{array}$ \\
\hline Other control variables[1] & Yes & Yes & Yes & Yes \\
\hline VDC FE & Yes & Yes & Yes & Yes \\
\hline Subject FE & No & Yes & No & Yes \\
\hline IMR & Yes & Yes & Yes & Yes \\
\hline Observations & 3734 & 22445 & 432 & 2584 \\
\hline R-squared & 0.471 & 0.168 & 0.675 & 0.332 \\
\hline
\end{tabular}

Robust standard errors in parentheses; *** $\mathrm{p}<0.01,{ }^{* *} \mathrm{p}<0.05,{ }^{*} \mathrm{p}<0.1$

[1] Other control variables are as in Table 5. 
Table 10. Total standardised estimates with private aided (semi-public) schools as a separate category

\begin{tabular}{lcc}
\hline & $(1)$ & $(2)$ \\
Variables & 2004 & $2002-04$ \\
\hline Log exp. per student (LEXP) & -0.112 & -0.0829 \\
& $(0.0697)$ & $(0.0572)$ \\
Private aided school (PA) & -0.0581 & -0.0249 \\
& $(0.179)$ & $(0.146)$ \\
Company-run school (CO) & $0.915^{* * *}$ & $0.809^{* * *}$ \\
& $(0.248)$ & $(0.206)$ \\
Trust-run school (TR) & -0.285 & -0.153 \\
& $(0.588)$ & $(0.476)$ \\
PA*LEXP & 0.0738 & 0.109 \\
& $(0.202)$ & $(0.190)$ \\
CO*LEXP & 0.144 & 0.165 \\
& $(0.114)$ & $(0.101)$ \\
TR*LEXP & $0.735^{* * *}$ & $0.639 * *$ \\
& $(0.251)$ & $(0.204)$ \\
Constant & $1.802^{* * *}$ & $1.544 * *$ \\
& $(0.336)$ & $(0.304)$ \\
IMR & Yes & Yes \\
Other control variables & Yes & Yes \\
VDC FE & Yes & Yes \\
SLC Year & No & Yes \\
Observations & 4,552 & 7,831 \\
R-squared & 0.435 & 0.418 \\
\hline
\end{tabular}

Robust standard errors in parentheses; *** $\mathrm{p}<0.01,{ }^{* *} \mathrm{p}<0.05, * \mathrm{p}<0.1$. Other control variables are as in Table 5. 


\section{Appendix}

Table A1. 2004 Means and standard deviations of regression variables

\begin{tabular}{lccc}
\hline Variable & Observations & Mean & Std. Dev. \\
\hline Total standardised SLC score & 3847 & 0.09912 & 0.98328 \\
Male & 3847 & 0.5555 & 0.49698 \\
Age at slc & 3847 & 16.686 & 3.66189 \\
Ill health & 3847 & 0.11048 & 0.31352 \\
Received help from peer & 3847 & 0.87497 & 0.3308 \\
No repetition at grade 9 & 3847 & 0.82714 & 0.37818 \\
Graduate in family & 3847 & 0.19704 & 0.39781 \\
Household expenditure decile & 3739 & 5.64616 & 2.80367 \\
LEXP & 3847 & 1.1668 & 0.67407 \\
CO & 3847 & 0.17494 & 0.37997 \\
TR & 3847 & 0.01664 & 0.12792 \\
CO*LEXP & 3847 & 0.30143 & 0.69232 \\
TR*LEXP & 3847 & 0.03646 & 0.28764 \\
Rural & 3846 & 0.67317 & 0.46912 \\
\hline
\end{tabular}


Table A2. 2004 estimates of total standardised test scores using teacher's salary expenditure per student

\begin{tabular}{lccc}
\hline & $(1)$ & $(2)$ & $(3)$ \\
Variables & All & Rural & Urban \\
\hline & & & \\
Log salary per student & -0.0939 & -0.0542 & -0.0411 \\
(LSALARY) & & & \\
& $(0.0755)$ & $(0.0760)$ & $(0.128)$ \\
Company-run school (CO) & $1.232 * * *$ & $1.061 * * *$ & $1.472 * * *$ \\
& $(0.226)$ & $(0.204)$ & $(0.266)$ \\
Trust-run school (TR) & -0.860 & -0.935 & -1.065 \\
& $(0.527)$ & $(0.569)$ & $(0.750)$ \\
CO*LSALARY & -0.0563 & -0.0779 & -0.167 \\
& $(0.176)$ & $(0.173)$ & $(0.169)$ \\
TR*LSALARY & $1.273^{* * *}$ & $1.419 * * *$ & $1.330 * * *$ \\
& $(0.317)$ & $(0.342)$ & $(0.449)$ \\
Intercept & $2.308^{* * *}$ & $2.316 * * *$ & 3.554 \\
& $(0.400)$ & $(0.453)$ & $(3.874)$ \\
IMR & Yes & Yes & Yes \\
VDC FE & Yes & Yes & Yes \\
Other control variables[1] & Yes & Yes & Yes \\
Observations & 3655 & 2417 & 1237 \\
R-squared & 0.466 & 0.361 & 0.559 \\
\hline \multicolumn{1}{c}{ Robust standard errors in parentheses; *** $\mathrm{p}<0.01, * * \mathrm{p}<0.05, * \mathrm{p}<0.1$}
\end{tabular}

[1] Other control variables are as in Table 5. 
Table A3. Estimates of 2002-04 estimates including school type-level time trends

\begin{tabular}{llll}
\hline & $(1)$ & $(2)$ & $(3)$ \\
Variables & All & Rural & Urban \\
\hline Log exp. per student (LEXP) & 0.0553 & 0.0880 & 0.0992 \\
& $(0.0641)$ & $(0.0766)$ & $(0.0940)$ \\
Company-run school (CO) & $0.945^{* * *}$ & $0.618^{* * *}$ & $1.320^{* * *}$ \\
& $(0.207)$ & $(0.203)$ & $(0.291)$ \\
Trust-run school (TR) & -0.416 & -0.353 & -0.700 \\
& $(0.382)$ & $(0.297)$ & $(0.488)$ \\
CO*LEXP & 0.0487 & 0.175 & -0.141 \\
& $(0.110)$ & $(0.130)$ & $(0.137)$ \\
TR*LEXP & $0.735^{* * *}$ & $0.605^{* * *}$ & $0.845^{* * *}$ \\
& $(0.170)$ & $(0.161)$ & $(0.216)$ \\
Rural & $-0.249^{* * *}$ & Dropped & Dropped \\
& $(0.0726)$ & & \\
Constant & $2.868^{* * *}$ & $2.899^{* * *}$ & 1.311 \\
& $(0.302)$ & $(0.337)$ & $(3.074)$ \\
Other control variables[1] & Yes & Yes & Yes \\
IMR & Yes & Yes & Yes \\
VDC FE & Yes & Yes & Yes \\
SLC year FE & Yes & Yes & Yes \\
CO*SLC year FE & Yes & Yes & Yes \\
TR*SLC year FE & Yes & Yes & Yes \\
Observations & 6431 & 4199 & 2232 \\
R-squared & 0.445 & 0.361 & 0.504 \\
\hline \multicolumn{1}{c}{ Robust standard errors in parentheses; *** p<0.01, ** $\mathrm{p}<0.05, * \mathrm{p}<0.1$} \\
\end{tabular}

[1] Other control variables are as in Table 5. 
Table A4. Estimates of total standardised test scores using pupil-teacher ratio

\begin{tabular}{lcc}
\hline & $(1)$ & $(2)$ \\
Variables & 2004 & $2002-04$ \\
\hline & & \\
Pupil-teacher ratio (PTR) & -0.000489 & -0.000712 \\
& $(0.00163)$ & $(0.00152)$ \\
Company-run school (CO) & $0.750^{* *}$ & $0.781^{* * *}$ \\
& $(0.348)$ & $(0.285)$ \\
Trust-run school (TR) & $3.595^{* * *}$ & $3.235^{* * *}$ \\
& $(1.129)$ & $(0.704)$ \\
CO*PTR & 0.0165 & 0.0117 \\
& $(0.0132)$ & $(0.0105)$ \\
TR*PTR & $-0.100^{* *}$ & $-0.0879 * * *$ \\
& $(0.0483)$ & $(0.0297)$ \\
Constant & $2.225^{* * *}$ & $2.436^{* * *}$ \\
& $(0.373)$ & $(0.281)$ \\
VDC FE & Yes & Yes \\
SLC FE & No & Yes \\
Other controls & Yes & Yes \\
Observations & 3739 & 6434 \\
R-squared & 0.460 & 0.428 \\
Robust standard errors in parentheses; $* * * \mathrm{p}<0.01, * *$ & $\mathrm{p}<0.05, * \mathrm{p}<0.1$
\end{tabular}


Table A5. Subject FE multinomial logit estimates of school choice (stage 1) 2004

\begin{tabular}{lcc}
\hline Variables & $(1)$ & $(2)$ \\
& Company-run & Trust School \\
School & \\
\hline \multirow{2}{*}{ Male } & $0.608^{* * *}$ & $0.753^{* * *}$ \\
Age (at SLC year) & $(0.144)$ & $(0.251)$ \\
& -0.140 & 1.561 \\
Age-squared & $(0.110)$ & $(3.794)$ \\
& 0.00114 & -0.0564 \\
Graduate in family & $(0.000968)$ & $(0.114)$ \\
& -0.0271 & 0.0148 \\
Quintile & $(0.122)$ & $(0.274)$ \\
& $0.405^{* * *}$ & $0.354 *$ \\
Janajati & $(0.0418)$ & $(0.205)$ \\
& 0.231 & $-1.128^{* *}$ \\
Dalit & $(0.223)$ & $(0.565)$ \\
& $-0.988^{* * *}$ & -1.063 \\
Chhetri & $(0.349)$ & $(0.692)$ \\
& 0.261 & -0.160 \\
Government school nearby & $(0.212)$ & $(0.362)$ \\
& $1.883^{* * *}$ & 0.740 \\
Constant & $(0.683)$ & $(0.967)$ \\
& $-3.438^{*}$ & -16.43 \\
VDC FE & $(1.925)$ & $(32.55)$ \\
Observations & Yes & Yes \\
Robust standard errors in parentheses; $* * * \mathrm{p}<0.01, * *$ & $\mathrm{p}<0.05, * \mathrm{p}<0.1$ \\
& &
\end{tabular}


Table A6. Multinomial logit estimates of school choice including private aided (PA) schools

\begin{tabular}{|c|c|c|c|c|c|c|}
\hline & \multicolumn{3}{|c|}{ 2002-04 } & \multicolumn{3}{|c|}{2004} \\
\hline & (1) & $(2)$ & $(3)$ & (4) & $(5)$ & $(6)$ \\
\hline Variables & PA & Trust & Company-run & PA & Trust & Company-run \\
\hline \multirow[t]{2}{*}{ Male } & $-0.197 *$ & 0.188 & $0.503 * * *$ & $-0.318 * *$ & $0.489 *$ & $0.646 * * *$ \\
\hline & $(0.100)$ & $(0.195)$ & $(0.139)$ & $(0.127)$ & $(0.289)$ & $(0.142)$ \\
\hline \multirow[t]{2}{*}{ Age (at SLC year) } & 0.0833 & $3.652 * *$ & -0.0648 & 0.0473 & 0.949 & -0.128 \\
\hline & $(0.0647)$ & $(1.536)$ & $(0.0871)$ & $(0.0832)$ & (1.471) & $(0.109)$ \\
\hline \multirow[t]{2}{*}{ Age-squared } & -0.000860 & $-0.105 * *$ & 0.000493 & -0.000526 & -0.0290 & 0.00104 \\
\hline & $(0.000590)$ & $(0.0474)$ & $(0.000768)$ & $(0.000738)$ & $(0.0438)$ & $(0.000955)$ \\
\hline \multirow[t]{2}{*}{ Graduate in family } & -0.0247 & 0.185 & -0.0872 & 0.00428 & 0.157 & 0.00324 \\
\hline & $(0.110)$ & $(0.114)$ & $(0.105)$ & $(0.132)$ & $(0.193)$ & $(0.116)$ \\
\hline \multirow[t]{2}{*}{ Quintile } & $-0.100 * *$ & $0.286 * *$ & $0.420 * * *$ & $-0.107 * *$ & 0.252 & $0.404^{* * *}$ \\
\hline & $(0.0411)$ & $(0.142)$ & $(0.0367)$ & $(0.0454)$ & $(0.157)$ & $(0.0417)$ \\
\hline \multirow[t]{2}{*}{ Janajati } & $0.389 *$ & -0.503 & 0.318 & $0.448 *$ & -0.457 & 0.304 \\
\hline & $(0.208)$ & $(0.372)$ & $(0.201)$ & $(0.236)$ & $(0.399)$ & $(0.222)$ \\
\hline \multirow[t]{2}{*}{ Dalit } & -0.201 & -0.722 & $-0.518 *$ & -0.0750 & -0.744 & $-0.937 * * *$ \\
\hline & $(0.197)$ & $(0.646)$ & $(0.299)$ & $(0.216)$ & $(0.681)$ & (0.348) \\
\hline \multirow[t]{2}{*}{ Chhetri } & 0.104 & -0.365 & 0.238 & 0.156 & -0.395 & 0.250 \\
\hline & $(0.179)$ & $(0.321)$ & $(0.179)$ & $(0.201)$ & $(0.386)$ & $(0.207)$ \\
\hline \multirow[t]{2}{*}{ Government school nearby } & $-0.736 *$ & -1.090 & $1.746 * * *$ & $-0.769 * *$ & -1.159 & $1.728 * *$ \\
\hline & $(0.376)$ & $(0.950)$ & $(0.652)$ & $(0.392)$ & $(0.955)$ & $(0.682)$ \\
\hline \multirow[t]{2}{*}{ Rural } & 0.167 & $-1.352 * *$ & 0.0912 & 0.0363 & $-1.546 * *$ & 0.0594 \\
\hline & $(0.344)$ & (0.616) & (0.341) & $(0.371)$ & $(0.642)$ & $(0.378)$ \\
\hline \multirow[t]{2}{*}{ Constant } & $-2.219 * *$ & $-34.77 * * *$ & $-4.209 * * *$ & -1.436 & -10.86 & $-3.560 *$ \\
\hline & (1.129) & (13.07) & (1.601) & $(1.346)$ & $(12.80)$ & (1.929) \\
\hline VDC FE & Yes & Yes & Yes & Yes & Yes & Yes \\
\hline SLC Year FE & Yes & Yes & Yes & No & No & No \\
\hline Observations & 9,666 & 9,666 & 9,666 & 5,612 & 5,612 & 5,612 \\
\hline
\end{tabular}

